\title{
Evaluating system of rice intensification using a modified transplanter: A smart farming solution toward sustainability of paddy fields in Malaysia
}

\author{
Redmond R. Shamshiri ${ }^{1,3^{*}}$, Bala Ibrahim², Siva K. Balasundram ${ }^{3}$, Sima Taheri ${ }^{4}$, Cornelia Weltzien ${ }^{1,5}$ \\ (1. Leibniz Institute for Agricultural Engineering and Bioeconomy, Max-Eyth-Allee 100, 14469 Potsdam-Bornim, Germany; \\ 2. Smart Farming Technology Research Center, Department of Agricultural and Biological Enginieering, Universiti Putra Malaysia; \\ 3. Department of Agriculture Technology, Faculty of Agriculture, Universiti Putra Malaysia, 43400, Serdang, Selangor, Malaysia; \\ 4. Centre of Research in Biotechnology for Agriculture (CEBAR), University of Malaya, 50603, Kuala Lumpur, Malaysia; \\ 5. Agromechatronics, Institute of Machine Design and Systems, Technische Universitaet Berlin, Germany)
}

\begin{abstract}
This paper presents the study reports on evaluating a new transplanting operation by taking into accounts the interactions between soil, plant, and machine in line with the System of Rice Intensification (SRI) practices. The objective was to modify planting claw (kuku-kambing) of a paddy transplanter in compliance with SRI guidelines to determine the best planting spacing $(S)$, seed rate $(G)$ and planting pattern that results in a maximum number of seedling, tillers per hill, and yield. Two separate experiments were carried out in two different paddy fields, one to determine the best planting spacing ( $S=4$ levels: $\mathrm{s}_{1}=0.16 \mathrm{~m} \times 0.3 \mathrm{~m}, \mathrm{~s}_{2}=0.18 \mathrm{~m} \times 0.3 \mathrm{~m}, \mathrm{~s}_{3}=0.21 \mathrm{~m} \times 0.3 \mathrm{~m}$, and $\mathrm{s}_{4}=0.24 \mathrm{~m} \times 0.3 \mathrm{~m}$ ) for a specific planting pattern (row mat or scattered planting pattern), and the other to determine the best combination of spacing with seed rate treatments $(G=2$ levels: $\mathrm{g}_{1}=75 \mathrm{~g} /$ tray, and $\mathrm{g}_{2}=\quad 240 \mathrm{~g} /$ tray). Main SRI management practices such as soil characteristics of the sites, planting depth, missing hill, hill population, the number of seedling per hill, and yield components were evaluated. Results of two-way analysis of variance with three replications showed that spacing, planting pattern and seed rate affected the number of one-seedling in all experiment. It was also observed that the increase in spacing resulted in more tillers and more panicle per plant, however hill population and sterility ratio increased with the decrease in spacing. While the maximum number of panicles were resulted from scattered planting at $\mathrm{s}_{4}=0.24 \mathrm{~m} \times 0.3 \mathrm{~m}$ spacing with the seed rate of $\mathrm{g}_{1}=75 \mathrm{~g} /$ tray, the maximum number of one seedling were observed at $\mathrm{s}_{4}=0.16 \mathrm{~m} \times 0.3 \mathrm{~m}$. The highest and lowest yields were obtained from $75 \mathrm{~g}$ seeds per tray scattered and $70 \mathrm{~g}$ seeds per tray scattered treatment respectively. For all treatments, the result clearly indicates an increase in yield with an increase in spacing.
\end{abstract}

Keywords: system of rice intensification, sustainable cultivation, smart farming, modified transplanter, paddy fields, Malaysia DOI: $10.25165 /$ j.ijabe.20191202.2999

Citation: Shamshiri R R, Ibrahim B, Balasundram S K, Taheri S, Weltzien C. Evaluating system of rice intensification using a modified transplanter: A smart farming solution toward sustainability of paddy fields in Malaysia. Int J Agric \& Biol Eng, 2019; 12(2): 54-67.

\section{Introduction}

The global increase in population and limitation of agricultural lands necessitate mechanization, efficiency, and productivity in all stages of rice production. For most Asian countries, rice is a staple food and a strategic crop ${ }^{[1]}$. System of Rice Intensification (SRI) is an agricultural system consistent with Sustainable Agriculture (SA) as well as Conservative Agriculture (CA) contributing in the preservation of natural resources like water and land and reducing chemical applied to crops and the pollution of the environment. The method was first introduced and

Received date: 2017-11-14 Accepted date: 2018-12-30

Biographies: Bala Ibrahim, MSc, Scientific Staff, research interests: agricultural machinery and mechanization, Email: balaibrahim58@gmail.com; Siva K. Balasundram, $\mathrm{PhD}$, Associate Professor, research interests: precision agriculture, information system, Email: siva@upm.edu.my; Sima Taheri, PhD, Post-doctoral fellow, research interests: molecular plant breeding, Email: sima_taheri@um.edu.my; Cornelia Weltzien, PhD, Professor and Chair of Agromechatronics, research interests: mechanical engineering and control systems, Email: CWeltzien@atb-potsdam.de.

*Corresponding author: Redmond R. Shamshiri, PhD, research interests: dynamic simulation and modeling. Leibniz Institute for Agricultural Engineering and Bioeconomy, Max-Eyth-Allee 100, 14469 Potsdam-Bornim, Germany. Tel: +49(0)331-5699422, Email: rshamshiri@atb-potsdam.de. implemented by de Laulanié ${ }^{[2]}$ to improve rice yield through manipulation of genetic capability, creating conducive environment, improving soil condition, and reducing production inputs ${ }^{[3]}$. Several technical reviews for adaptation and improvement of $\mathrm{SRI}^{[4-8]}$, along with comprehensive discussions on water management ${ }^{[9-11]}$, productivity, and other research issues in the past ten years are available in the published literatures ${ }^{[12-15]}$. Research attempts have been made to develop fully-automated mechanical paddy transplanters in compliance with SRI guidelines ${ }^{[16,17]}$ that reduce man-days per hectare and increase output. A good example of such efforts is a mechanized water-wheeled semi-automated transplanter that was custom designed and developed in Punjab, India ${ }^{[7]}$. More recently, a modern rice seed broadcasting approach was designed and tested by Li et al. ${ }^{[18]}$ using an unmanned aerial vehicle. Another novel technique was introduced by Zhang et al. ${ }^{[19]}$ by means of a pneumatic rice seed metering device that has sucking hole plates through which 3 to 4 seeds are sucked synchronously and released into paddy fields for hybrid rice direct seeding.

Malaysia's paddy fields are suffering from lack of modern cultivation practices, a threat that heavily affects optimum rice production capacity. Some of the challenges for Malaysian rice growers include proper management of land and water resources, declining yields due to operational holding-size shrinkage and 
stagnation, infestation of weeds, diseases outbreaks due to over usage of pesticides, labor shortage and efficient solution for shifting from manual to automated transplanting, and sustainability of the production. Visits to several paddy fields also revealed that plant population in manually operated fields is also very low and yield-decreasing. Local farmers reported that transplanting delays due to labor shortage result in a progressive decrease in yield. Implementation of smart farming solutions in commercial scale requires extensive research for evaluation of the proposed methods and the machinery involved. In order to keep the paddy fields profitable, it is necessary to provide Malaysian farmers with automated single-planting transplanters that eliminate manual operation.

The system of rice intensification suggests planting one seedling per hill to improve plant water intake, nutrient balance, and pest management. The space between planting seeds is recommended at $0.25 \mathrm{~m}$. This transplanting spacing has been reported to result in the best rice performance ${ }^{[20-22]}$. The effects of hill and plant spacing on yield and quality of rice have been discussed in numerous published works ${ }^{[9,23-35]}$. In general, rice yield can be significantly boosted with modern cultural practices such as control of inputs (i.e., fertilizer, nutrient, water, and spaying, and chemicals), ideal environmental parameters (air and soil temperature, humidity, solar radiation, soil moisture content and fertility), sensible planting and nursery, and optimum transplanting adjustments for best tillering ${ }^{[21,29,36]}$

Right spacing between seeds results into underground and aerial development by reducing the competing for nutrient and light, hence vegetative growth and grain yield will be increased. The effect of hill spacing's $(0.10 \mathrm{~m} \times 0.15 \mathrm{~m}, 0.2 \mathrm{~m} \times 0.15 \mathrm{~m}$ and $0.3 \mathrm{~m} \times$ $0.15 \mathrm{~m}$ ) on the quality and productivity of rice CV "Giza 177" was studied by Kandil et al. ${ }^{[28]}$ showing that the spacing of $0.2 \mathrm{~m} \times$ $0.15 \mathrm{~m}$ resulted the highest grain yield.ha ${ }^{-1}$, 1000-grain weight, panicle length, harvest index, head rice percentage, the best milling and protein content. In a different study, Salem ${ }^{[37]}$ investigated plant spacing in rice productivity and showed that that narrower spacing of $0.2 \mathrm{~m} \times 0.15 \mathrm{~m}$ (compared with wider spacing of $0.2 \mathrm{~m} \times$ $0.2 \mathrm{~m}$ and $0.2 \mathrm{~m} \times 0.25 \mathrm{~m}$ ) had the highest values of plant height, panicles $/ \mathrm{m}^{2}$, leaf area index, straw and grain yields, and number of days to heading. Same study also reported that the two wider spacing recorded the highest values for panicle weight and length, the number of filled grains per panicle, and 1000-grain weight. More studies on the effects of planting density on agronomical characteristics of rice are available in the previous works ${ }^{[24,38-43]}$. For the effects of row spacing on canopy structure and yield in different rice cultivars, Zhao et al. ${ }^{[31]}$ showed that the percentage of productive tiller was first reduced before it was increased with increasing of row-spacing following a quadratic regression pattern between row spacing and the percentage of productive tiller. Studying the effects of narrow spacing on yield loss for aerobic rice showed that regardless of the weed species and weed emergence date ${ }^{[44]}$, rice grain yields were higher in narrower rows ${ }^{[29,30]}$. Similar results was reported by Omin et al. ${ }^{[45]}$, where narrow spacing of $0.1 \times 0.20 \mathrm{~m}$ led to the highest yield and yield components of Giza177 rice cultivar compared with the two other treatments of $0.20 \times 0.20 \mathrm{~m}$ or $0.3 \times 0.2 \mathrm{~m}$. The best pattern for rice planting was reported by Islam et al. ${ }^{[46]}$ to be $0.25 \times 0.12 \mathrm{~m}$ compared with $0.15 \times 0.10 \mathrm{~m}$ and $0.20 \times 0.12 \mathrm{~m}$. Two different studies ${ }^{[47,48]}$ reported that space of $0.15 \mathrm{~m}$ between hills gives the highest number of panicles $/ \mathrm{m}^{2}$, the tallest plants, and maximum grains and straw yield, while hill spacing of $0.25 \mathrm{~m}$ gives the highest number of filled grains per panicle and 1000-grain weight. Practicing the best planting pattern, optimum transplanting spacing, and seed rate in compliance with SRI guideline is expected to significantly improve rice yield. Other than the works of Durairaj et al. ${ }^{[49,50]}$, the amount of published study that investigated the efficiency of a fully automated paddy transplanter for SRI is limited.

The demand for producing rice with higher yield and quality at lower costs necessitates practicing sustainable methods and smart farming technology in order to keep the production competitive through mechanization and automation. In this content, modification and development of a transplanter that comply with SRI specification should be investigated based on the plant physical and mechanical properties. Such machine design involves good understanding of the SRI operation and its functional requirements. For the purpose of this research, we modified planting claw (kuku-kambing) of an existing paddy transplanter (Kubota SPU-68C), as well as seed rate on tray and planting technique in such a way that it only picks one to two seedlings at a time to satisfy the specified guidelines of SRI for transplant seedlings at the recommended, spacing, quantity, moisture content, and age ${ }^{[51]}$. Seed selection criteria were embarked upon selecting healthier and vigorous seeds, while germination was count to determine the suitability of the planting medium in relation to the growth and development of the rice seedling and its easiness in single removal. The existing transplanter claw picked between 5-8 seedlings per hill for planting. Modification was required to allow planting pattern of different spacing with single seedling per hill at 2-3 cm planting depths. This paper reports the utilization of this modified transplanter in compliance with SRI guidelines to determine the best spacing, seed rate and planting pattern that resulted in a maximum number of seedling and tillers per hill.

\section{Materials and methods}

\subsection{Experiment setup}

The study was conducted during 2014 planting season (Jan-May) in two different rice irrigation schemes in the state of Selangor in Northwest of Malaysia. Selangor covers an approximate area of $20000 \mathrm{hm}^{2}$, extending over a length of 40 kilometers along the coast with a width of $5 \mathrm{~km}$ on average. About $17510 \mathrm{hm}^{2}$ of the total area are under paddy cultivation, while the remaining area, including $760 \mathrm{hm}^{2}$ is allocated for vegetables, $460 \mathrm{hm}^{2}$ for tree crops and $510 \mathrm{hm}^{2}$ lying idle. The main drainage and irrigation canals run parallel to the coast, which originated from the Bernam river, serving as the main source of water supply to the scheme. Two separate experiments were carried out in split block format with three replications, first to determine the best transplanting spacing ( $S=4$ levels: $\mathrm{s}_{1}=0.16 \mathrm{~m} \times$ $0.3 \mathrm{~m}, \mathrm{~s}_{2}=0.18 \mathrm{~m} \times 0.3 \mathrm{~m}, \mathrm{~s}_{3}=0.21 \mathrm{~m} \times 0.3 \mathrm{~m}$ and $\left.\mathrm{s}_{4}=0.24 \mathrm{~m} \times 0.3 \mathrm{~m}\right)$ for a specific planting pattern (row mat or scattered planting pattern), and the second to determine the best combination of transplanting spacing with seed rate treatments $\left(G=2\right.$ levels: $\mathrm{g}_{1}=$ $75 \mathrm{~g} /$ tray, and $\mathrm{g}_{2}=240 \mathrm{~g} /$ tray). The first experiment was conducted on a field size of width $=30 \mathrm{~m}$ by height $=12.4 \mathrm{~m}$, located at Ladang Sepuluh agricultural experimental station, inside the campus of Universiti Putra Malaysia (latitude: 3.002725, longitude: 101.703137). This field was split into two blocks, A and B, respectively assigned to row and scattered planting pattern using seed rate of $70 \mathrm{~g} /$ tray. The second experiment was conducted on a field size of width $=48 \mathrm{~m}$ by height $=27 \mathrm{~m}$ in the rice granary area of Tanjung Karang located at the flat coastal plain of Northwest 
Selangor Agricultural Development project (Latitude: 3.486775, Longitude: 101.163586). This field was also split into two blocks, $\mathrm{C}$ and $\mathrm{D}$, respectively assigned to the seed rate treatments of $75 \mathrm{~g} /$ tray and $240 \mathrm{~g} /$ tray, both with scattered planting pattern. Each block was divided into four experimental plots of equal size that were randomly assigned to the four levels of spacing treatment and the two levels of seed rate treatment as shown in Figure 1. Balanced factorial design with two-way analysis of variance (ANOVA) was used with equal replication of 3 measurements in each experimental plot to determine variation effects in the number of seedling per hill and tiller per hill due to different spacing, planting pattern and their interaction in block $\mathrm{A}$ and $\mathrm{B}$, and different spacing, seed rate and their interaction in block C and D. For the $k^{\text {th }}$ number of seedling per hill (or tiller per hill) under the $i^{\text {th }}$ level of spacing factor and the $j^{\text {th }}$ level of seed rate factor, the two-way ANOVA model was stated as $Y_{i j k}=\mu+s_{i}+g_{j}+(s . g)_{i j}+\varepsilon_{i j k}$. Table 1 provides a descriptive summary of the field blocks, experimental plots, and treatments.
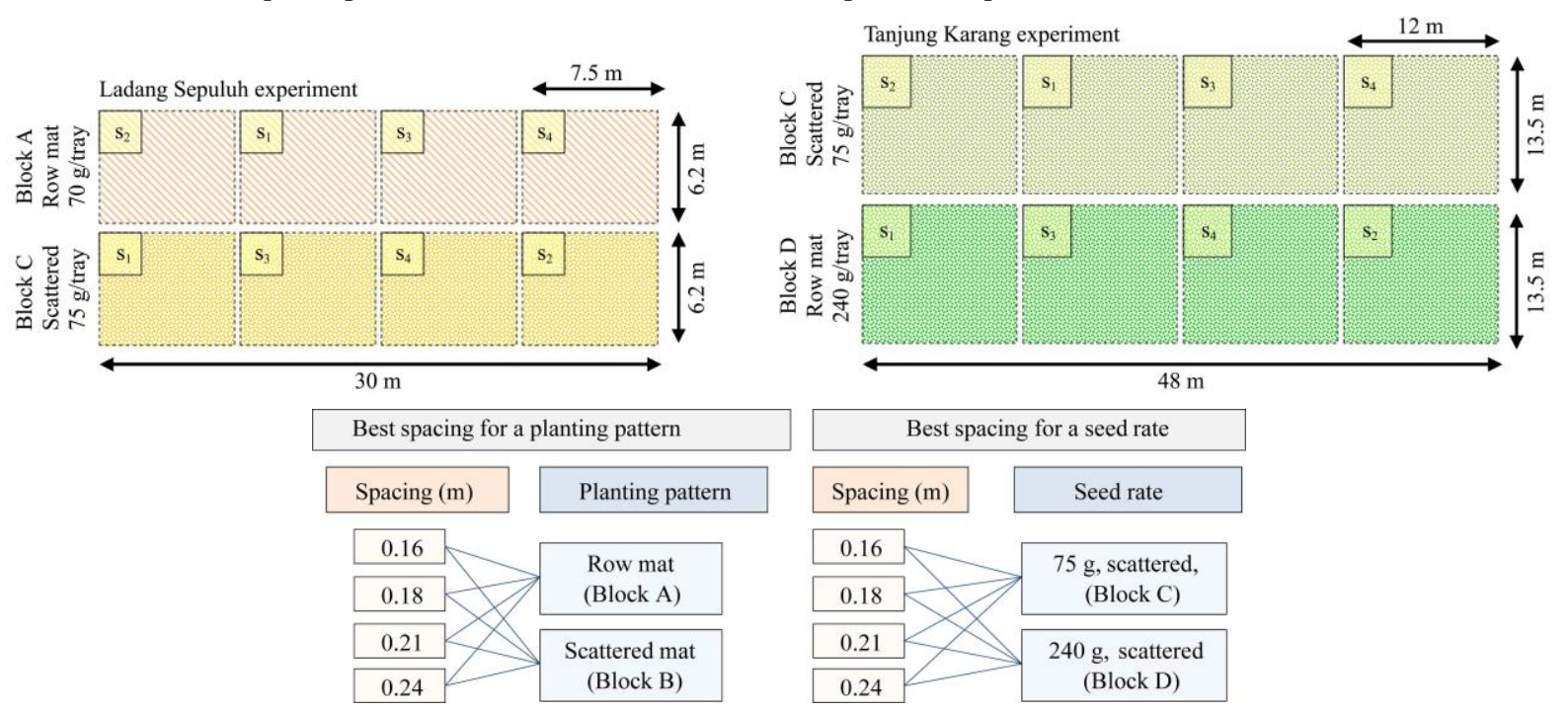

Figure 1 Schematic view of the rice fields under study and corresponding experimental design

Table 1 Description of field blocks and experimental fields

\begin{tabular}{ccccc}
\hline Field name & $\begin{array}{c}\text { Field size } \\
(\mathrm{W} \times \mathrm{H}) / \mathrm{m}\end{array}$ & $\begin{array}{c}\text { Plot size } \\
(\mathrm{W} \times \mathrm{H}) / \mathrm{m}\end{array}$ & $\begin{array}{c}\text { Seed } \\
(\mathrm{g} / \text { tray })\end{array}$ & $\begin{array}{c}\text { Planting } \\
\text { pattern }\end{array}$ \\
\hline Ladang Sepuluh Block A & $30 \times 6.2$ & $7.5 \times 6.2$ & 70 & Scattered \\
Ladang Sepuluh Block B & $30 \times 6.2$ & $7.5 \times 6.2$ & 70 & Row \\
Tanjung Karang Block C & $48 \times 13.5$ & $13.5 \times 12$ & 75 & Scattered \\
Tanjung Karang Block D & $48 \times 13.5$ & $13.5 \times 12$ & 240 & Scattered \\
\hline
\end{tabular}

\subsection{Field and seedling preparation}

Prior to tillage, both fields were prepared according to the paddy production practices recommended in the rice manual provided by the Department of Agriculture of Malaysia ${ }^{[52,53]}$. Residues and straw from the previous season's crop were burnt, and then tilled by rotary tillage pass in dry soil condition followed by two rotary tillage passes in $20-50 \mathrm{~mm}$ flooded condition of standing water. The field was cleared, harrowed, ploughed twice and puddled to create a comfortable growing condition to help the young delicate seedlings overcome the transplanting shock for quicker and easier establishment. The field was drained from the excess water a day before transplanting operation in order to meet the moisture requirements. The preparation of the land was similar to the conventional practice as suggested by Uphoff et al. $^{[6,54]}$ in which land leveling was pursuit vigorously for efficient distributing of the limited water across the whole land mass and at the same time providing drainage channels to manage the excess water either through irrigation or rainfall. Seeds were visually inspected to ensure that they are healthy and viable for sowing. Selected seeds based on health and vigorous criteria were incubated in moist gunny material for $2 \mathrm{~d}$. In order to attain the best seedling establishment, seeds were then put into a $2.5 \%$ solution of salt and water before laying them in fresh water for $24 \mathrm{~h}$ before sowing on January, $1^{\text {st }}, 2014$. It should be noted that the quality of seed is the primary mean used by paddy farmers in attaining the best seedling establishment as well as higher yield through uniformly free stress robust seedlings. Hence the seeds were submerged in different concentrations of $\mathrm{NaCl}_{2}$ (with $50 \mathrm{~g} / \mathrm{L}$, $60 \mathrm{~g} / \mathrm{L}$, and $80 \mathrm{~g} / \mathrm{L}$ of water, and distilled water only). The selected sunken seeds were set for the germination test to find the parameter that gives the best germination. Table 2 shows that the seeds soaked in distilled water had $99 \%$ germination potential while the seeds soaked in distilled water were used in the experiments in order to avoid missing hills during transplanting operation.

Table 2 Percentage of seed germination with respect to germination count

\begin{tabular}{|c|c|c|c|c|c|c|c|c|c|c|}
\hline \multirow{2}{*}{$\begin{array}{l}\text { Solution of } \\
\mathrm{NaCl}_{2} / \mathrm{g} \cdot \mathrm{L}^{-1}\end{array}$} & \multicolumn{10}{|c|}{ Day after sowing } \\
\hline & 1 & 2 & 3 & 4 & 5 & 6 & 7 & 8 & 9 & 10 \\
\hline 50 & 0 & 0 & 32 & 36 & 66 & 74 & 74 & 74 & 74 & 74 \\
\hline 60 & 0 & 0 & 30 & 78 & 84 & 90 & 90 & 90 & 90 & 90 \\
\hline 80 & 0 & 0 & 24 & 58 & 64 & 68 & 68 & 70 & 70 & 70 \\
\hline $\begin{array}{l}0 \text { (Distilled } \\
\text { water only) }\end{array}$ & 0 & 0 & 78 & 80 & 96 & 99 & 99 & 99 & 99 & 99 \\
\hline
\end{tabular}

Prepared seeds were uniformly scattered while some were planted in rows in the nursery beds at different seed rates of $70 \mathrm{~g} /$ tray, $75 \mathrm{~g} /$ tray and $240 \mathrm{~g} /$ tray, followed by half burnt rice husk of $1 \mathrm{~cm}$ thickness to cover the seeds, then tendering and watering for $14 \mathrm{~d}$. Transplanting operation was performed on January, $15^{\text {th }}$, 2014. Duration of uprooting seedling from seedling tray to transplanting in the main field was $15-30 \mathrm{~min}$. A summary of the nursery practice involved in raising the conventional seedlings is provided in Figure 2. A tray was designed (Figure 3) for a special seedling raising technique called mat or dapog. In this technique sprouted seeds are spread uniformly on a half burnt rice husk covered with the seedling tray for a duration of four days, watered with rose can, and transplanted to the field when the seedlings are about 2-3 leaf stage (14 d) as shown in Figure 4. 


\begin{tabular}{|c|c|c|}
\hline 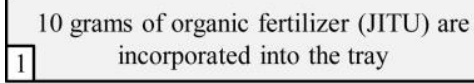 & $22^{310 \text { grams of rice husk added to the tray }}$ & 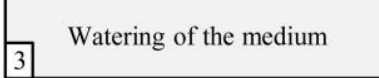 \\
\hline $470,75,240$ grams weighted seeds sown & $\begin{array}{r}\text { Tray stacked in an ensiled container for } \\
48 \mathrm{hr} \text {, sprinkled with water every } 24 \mathrm{hr} \\
5\end{array}$ & \begin{tabular}{|l} 
Day 3 paving of the nursery with \\
$6 \quad 70 \%$ light \\
\end{tabular} \\
\hline 7. Day 5 transferring to the main field & Tendering processes & $99^{\text {Day } 12 \text { Agronomic practices }}$ \\
\hline
\end{tabular}

Figure 2 Schematic illustration procedures for nursery tray practice requirements

-

40.0
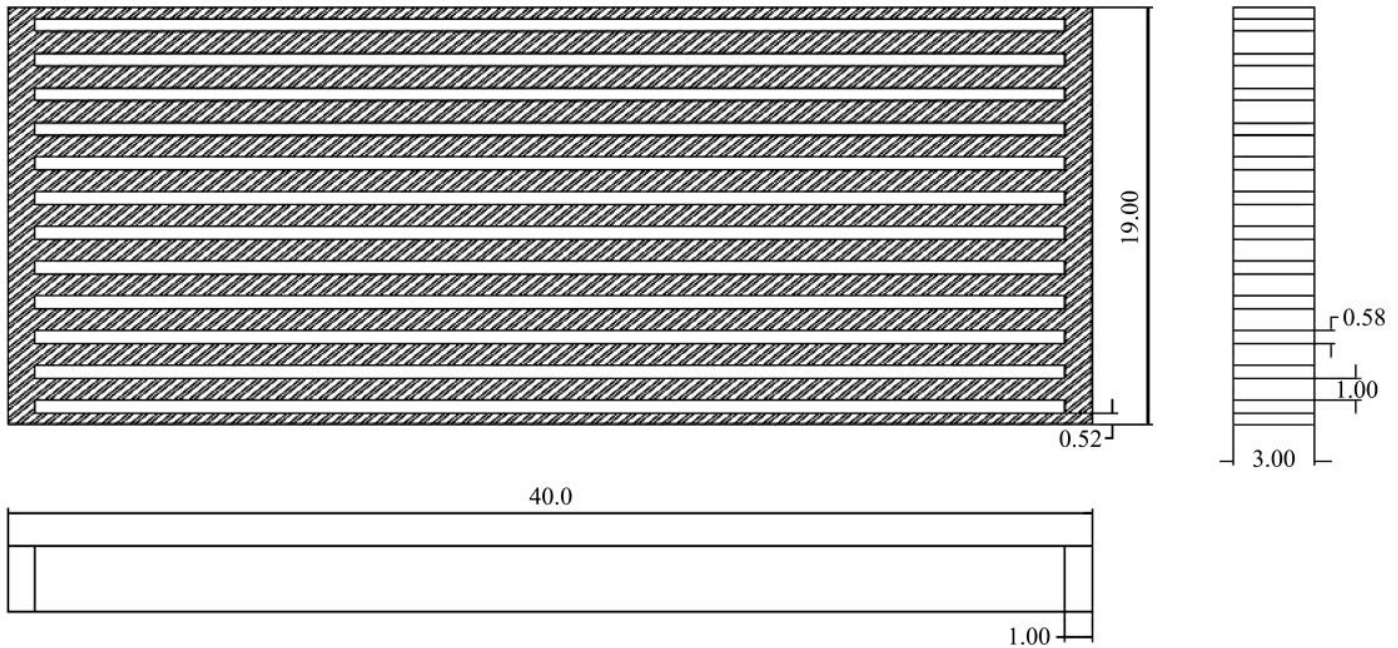

Figure 3 Tray design for modified seedling raising technique (mm)
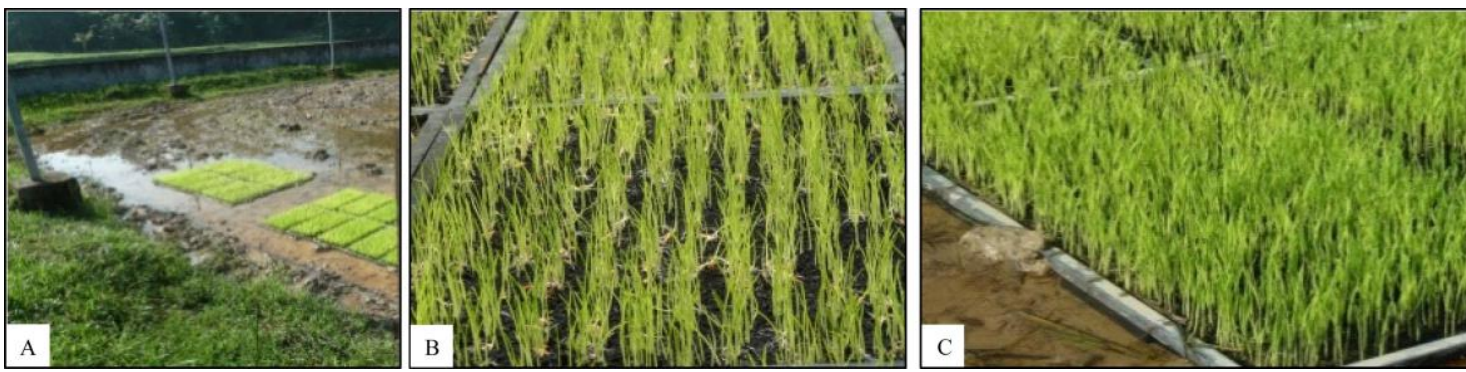

Figure 4 (A) Seedlings ready for transplanting, (B): Modified row pattern seed raising technique and

(C) Modified scattered pattern seed raising technique

\subsection{Transplanting and harvesting}

Transplanting was carried out using Kubota self-propelled transplanter model NSPU-68C (Kubota Corporation, Osaka, Japan) operating lengthwise of the prepared fields at different hills spacing, with the soil kept moist enough to prevent floating of the tiny friable seedlings. The plant characteristics at transplanting time consisted of 2-3 leaves, $2 \mathrm{~mm}$ stem thickness, $19 \mathrm{~mm}$ stem length and $3.5 \mathrm{~mm}$ root length. The machine was operating at gear position 3 and transplanting at $3 \mathrm{~mm}$ depth. It had a fixed row to row spacing of $0.30 \mathrm{~m}$ and a variable plant to plant spacing of $0.14 \mathrm{~m}, 0.16 \mathrm{~m}, 0.18 \mathrm{~m}, 0.21 \mathrm{~m}$ and $0.24 \mathrm{~m}$. Two modifications were applied on the existing transplanter, one on the planting claw (kuku kambing) in a way that it only catches one to two seedlings at a time and place it in moist soil (the original setup removed 5-8 seedlings per hill), and the second involved redesigning and modification of the seedling raising techniques to reduce plant density per unit area. To this aim, the original $12 \mathrm{~mm}$ conventional claw of the transplanter was replaced with a modified claw consisting of $9 \mathrm{~mm}$ claw size shown in Figure 5 to reduce planting density. The transplanting operation and the appearance of the seedlings after transplanting are shown in Figure 6. The soil was continuously flooded for $30 \mathrm{~d}$ after transplanting and was then irrigated at weekly intervals. A new high-yield local cultivar, MR219, developed by the Malaysian Agricultural Research and Development Institute (MARDI) was used in the experiment. Conventional recommendations for insects and disease control were followed. Rotary weeding was done during the entire crop growth period. Alternate wetting and drying were maintained at the vegetative stage, while during the flowering stage until 10-12 d prior to harvesting, a thin layer of water maintained through irrigation at frequent interval. Fields were drained two weeks prior to harvesting. Harvesting operation was performed at full physiological maturity using New Howland 1545 self-propelled combine harvester model 1545 (New Holland Agriculture, Turin, Italy) powered by an $82.06 \mathrm{~kW}$ diesel engine. The numbers of transplanted hills in each block are given in Table 3 .

Table 3 Number of transplanted hills

\begin{tabular}{ccc}
\hline \multirow{2}{*}{ Spacing } & \multicolumn{2}{c}{ Actual hill transplanted } \\
\cline { 2 - 3 } & A and B & C and D \\
\hline 16 & 779 & 3317 \\
18 & 685 & 2968 \\
21 & 498 & 2531 \\
24 & 514 & 2240 \\
\hline
\end{tabular}



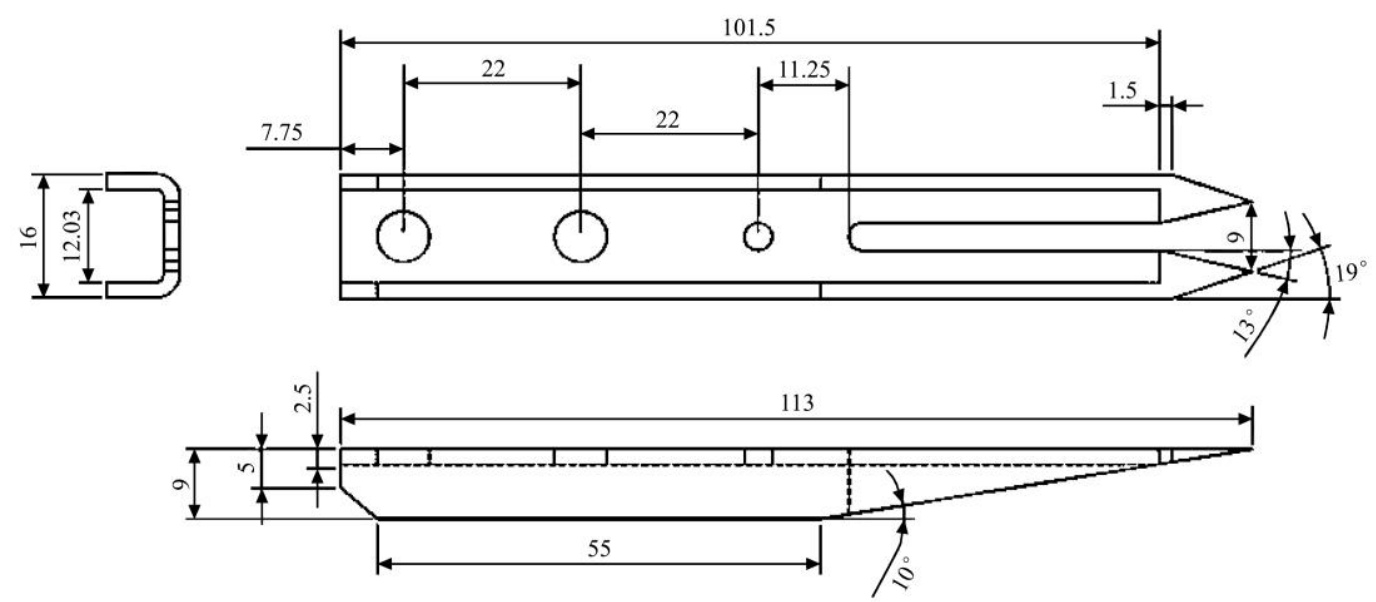

Figure 5 Dimensional specification of the modified UPM Kuku-kambing
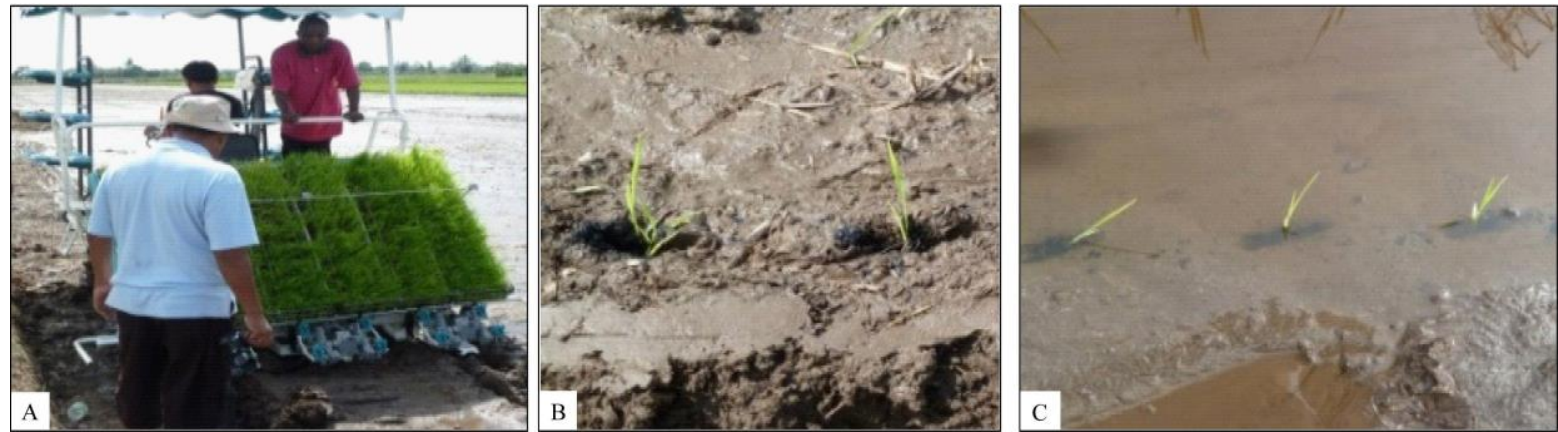

Figure 6 (A) Transplanting operation, (B) Single seedling transplanting on the go, and (C) three days seedlings after transplanting

\subsection{Soil Physical and chemical properties analysis}

Physiochemical characteristics of the experimental soil were analyzed to determine soil properties in both fields. The materials used in soil analysis experiment included a set of sieves, containers, weighing scale with an accuracy of $0.001 \mathrm{~g}$, shaker, soil auger, electrical drying oven, hammer, measuring cylinder and pipette. Two soil samples were collected from each experimental plots with a core sampler from top soil layer at a depth of 0-100 $\mathrm{mm}$. The sampler was driven manually using a hammer. Collected samples were wrapped in plastic bags for immediate analysis in the soil laboratory to determine dry bulk density and particles properties. The air dried samples were used for soil particle size (texture) analysis. The standard gravimetric method by oven-dry at the temperature of $105^{\circ} \mathrm{C}^{[55]}$ was used to determine moisture content. The initial samples were first weighed to determine weight mass and were then placed in an electric oven at a temperature setting of $105^{\circ} \mathrm{C}$ for $24 \mathrm{~h}$ for weighing the dry mass. The percentage of water content $(W)$ was defined as the ratio between the differences in sample's wet and dry mass according to Equation (1) ${ }^{[56]}$.

$$
W=100 \frac{M_{c w s}-M_{C S}}{M_{C S}-M_{C}}
$$

where, $M_{c w s}$ is the mass of container and wet specimen, $\mathrm{g} ; M_{C S}$ is the mass of container and oven dry specimen, $\mathrm{g} ; M_{C}$ is the mass of container, g.

This equation can be expressed as $W=100 M_{W} / M_{S}$ is mass of solid particles, g; $M_{W}$ is mass of water, g. Soil bulk density was measured by the standard core method ${ }^{[57]}$. The particle size distribution (PSD) of the soil was determined using the Pipette method for Malaysian soils as described in [58]. Percentages of sand $(>50 \mu \mathrm{m})$, silt $(2-50 \mu \mathrm{m})$ and clay $(<2 \mu \mathrm{m})$ were determined and used in identifying the textural class from the textural triangle. Soil samples were sieved through $2 \mathrm{~mm}$ sieve size. The organic matter was removed by heating $100 \mathrm{~g}$ sample with hydrogen peroxide which absorbed cations were removed by treating the sample with 0.2 drops of hydrochloric acid and then dispersed in Calgon. The sand $(2-50 \mu \mathrm{m})$ was separated through sieving process while silt $(2-5 \mu \mathrm{m})$ and clay $(<2 \mu \mathrm{m})$ were determined by Pipette Method.

Soil texture at planting time was analyzed in the laboratory for all four experimental blocks and was found to be fine to fine granular structure classified as clay silt loam texture based on the soil charts ${ }^{[58]}$. The percentage of sand, silt, and clay, as well as the $\mathrm{pH}$ level, moisture content (MC), bulk density (BD), amount of nitrogen $(\mathrm{N})$, phosphorous $(\mathrm{P})$, potassium $(\mathrm{K})$, electrical conductivity are reported in Table 4 . A bulk density of $0.86 \mathrm{~g} / \mathrm{cm}^{3}$ and $0.88 \mathrm{~g} / \mathrm{cm}^{3}$ for Ladang sepuluh (block A and B) and Tanjung Karang (block C and D) was respectively obtained using standard technique of core sample method ${ }^{[57]}$, which are in agreement with Garg et al. ${ }^{[59]}$ recommendations that transplanting should not be done either on too soft nor too hard soil. Statistic summary of air temperature, relative humidity and wind speed during the five months of experiments were collected using a precision data acquisition system ${ }^{[60]}$ and are provided in Table 5.

\subsection{Data collection}

The number of plants per square meter was recorded 8 days after transplanting. After transplanting, from each of the experimental plots 20 samples of the seedling hill were uprooted and the depth measured, and later on re-planted manually. Randomly selected samples of 20 stands from each experimental plot were counted for the number of seedlings per hill and tillers per hill. After harvesting and threshing, the moisture content in grain was measured using MMG608 grain moisture meter (General tools, Secaucus, NJ) while the grain weight yield was expressed in $\mathrm{t} / \mathrm{hm}^{2}$. Observations on missing hill, number of seedlings per hill, tillers, panicle, and grain weight (yield) for the operation were 
recorded in order to evaluate the performance of the transplanter in the experimental sites. To determine the number of tillers per square meter, the numbers of panicle-bearing tillers were recorded at the harvesting time for one square meter from three different places in the experimental plots of each field and were averaged. Moreover, twenty panicles of primary tillers were selected randomly from earmarked areas in the plots during the harvesting period in order to find the number of grains per panicle. A demonstration of the field with rice seedling per stand and rice seedling at 90 days is shown in Figure 8. The performance of rice cultivation under SRI was determined by the higher number of tillers per hill, higher grains per panicles, lower percentage of empty seeds and higher yield. Yield component and yield data were collected prior to harvesting.
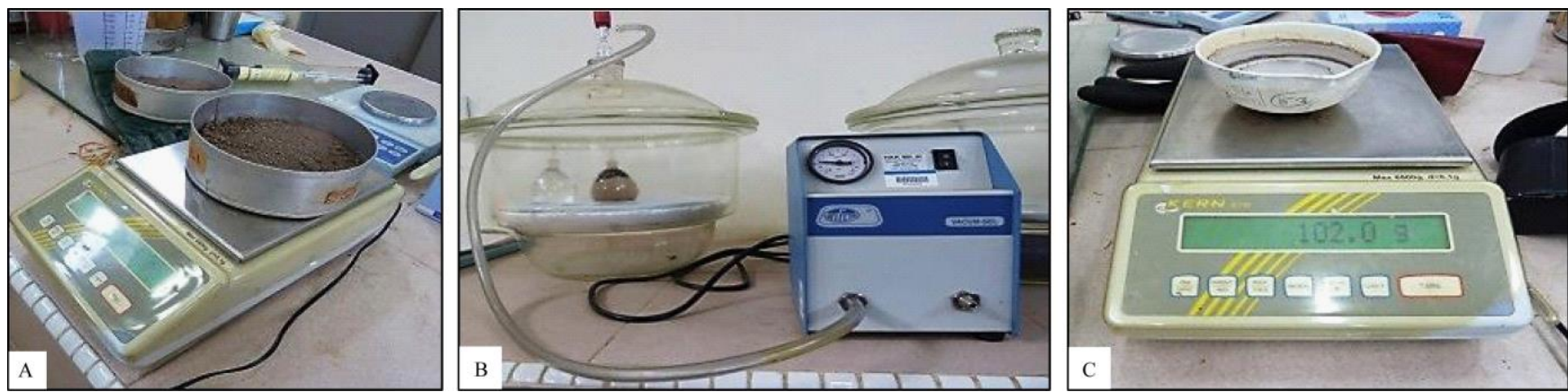

Figure 7 Soil analysis setup (A: weighing of soil sample, B: bulk density determinations, and C: soil particle determinations)

Table 4 Result of soil analysis in different experimental field

\begin{tabular}{cccccccccccccc}
\hline Sample & Sand/\% & Silt/\% & Clay/\% & $\mathrm{pH}$ & $\mathrm{MC} / \%$ & $\mathrm{BD} / \mathrm{g} \cdot \mathrm{cm}^{-3}$ & $\mathrm{~N} / \%$ & $\mathrm{P} / \mathrm{ppm}$ & $\mathrm{K} / \mathrm{ppm}$ & $\mathrm{EC} / \mathrm{ds} \cdot \mathrm{m}^{-1}$ & $\mathrm{Texture}$ & \\
\hline A & 42.82 & 32 & 25.18 & 5.5 & 64 & 0.86 & 0.18 & 36.8 & 28.2 & 1.8 & Clay silt loam \\
B & 43.35 & 31.8 & 24.85 & 5.5 & 64 & 0.86 & 0.18 & 36.8 & 28.2 & 1.8 & Clay silt loam \\
C & 42.45 & 31.3 & 26.25 & 7.1 & 67 & 0.88 & 0.17 & 35.4 & 26.7 & 1.9 & Clay silt loam \\
D & 41.8 & 31.65 & 26.55 & 7.1 & 66 & 0.88 & 0.18 & 35.6 & 27.4 & 1.9 & Clay silt loam \\
\hline
\end{tabular}

Table 5 Statistic summary of basic climate parameters during the experiment

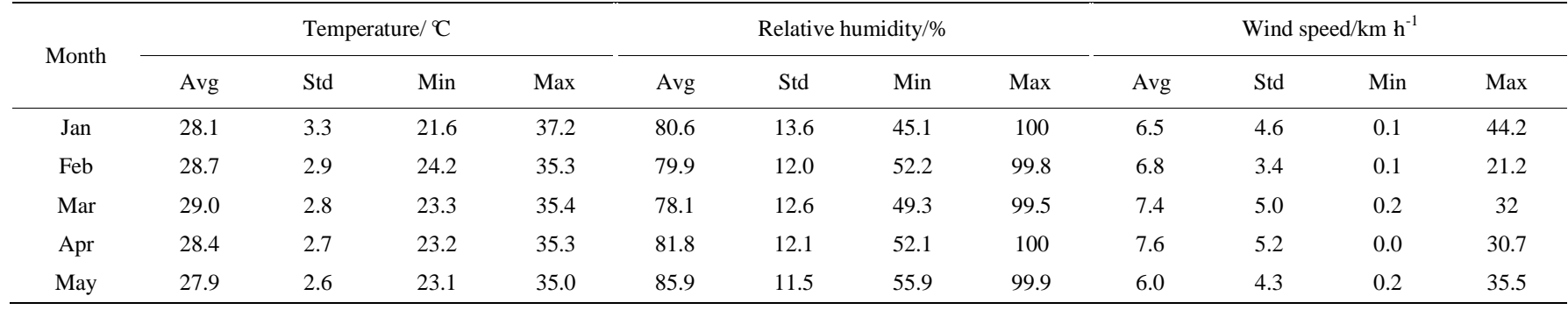
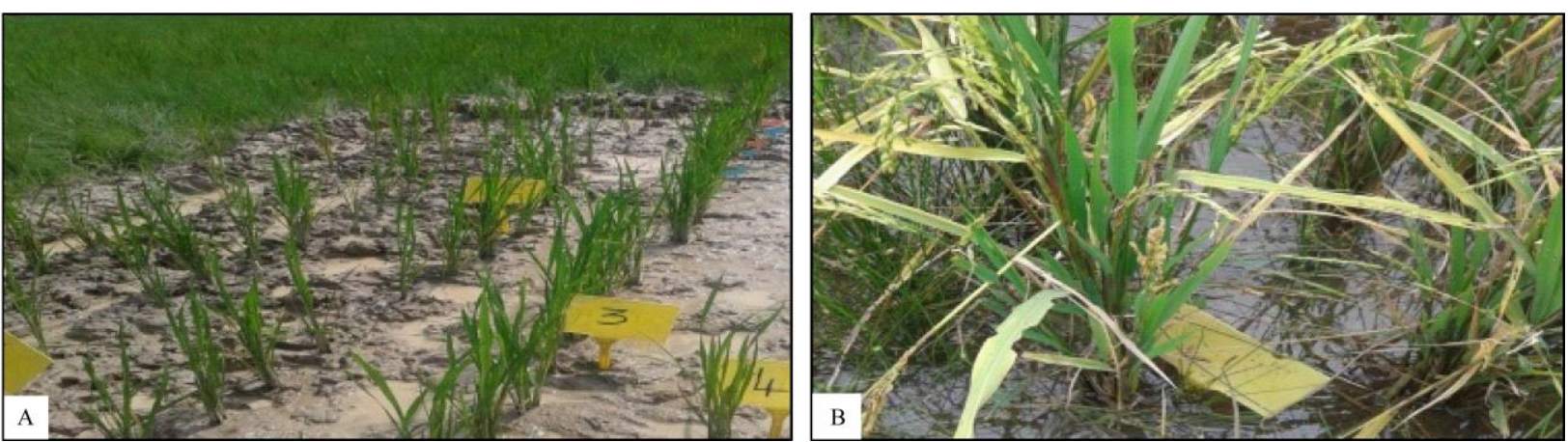

Figure 8 Rice seedling per stand (A) and rice seedling at $90 \mathrm{~d}$ (B)

\section{Results}

Major findings of this research are provided by means of tables and figures, with minor trends or non-significant trends covered through the text. We have summarized our findings in the following order: (i) hill population and missing hills, (ii) tiller population and seedling count, (iii) yield components, (v) and germination count. Moreover performance of the rice cultivation under SRI was determined by higher number of tillers per hill, higher grains per panicles, lower percentage of empty seeds and higher yield.

\subsection{Hill population and missing hills}

A summary of data for the effects of spacing and seed rate treatment on the number of hill population, percentage of missing hills, combined percentage of one and two-seedlings, and the percentage of good seeds is given in Table 6. Measurements from all experimental blocks showed that plants had mean stem thickness of $2.048 \pm 0.1 \mathrm{~cm}$ and mean root length of $3.538 \pm 0.07 \mathrm{~cm}$. The percentage of missing hill was observed to be fluctuating with increasing in hill spacing in $70 \mathrm{~g}$ row tray planting pattern, which is similar to the results obtained by Behera et al. ${ }^{[61,62]}$, while in the scattered tray planting pattern we had $1 \%, 2.5 \%, 2 \%$ and $2 \%$, of 
missing hill which shows the large dependency to the transplanter claw as well as the seedling density and the uniformity in the mat as reported by Mufti et al. ${ }^{[63]}$. It should be noted that the seedling needs to be smooth flowing to avoid problem of non-linearity in sliding of the mat on the tray in compliance with the SRI recommendations. Other noticeable factors in causing missing hill were the speed of lateral movement of the seedling tray, the thickness of the seedling mat, status of the standing water in the field as well as the accuracy of the different parts of the machine. It should be noted that at low sedimentation period, high water level leads to wave action resulting in seedlings wash-off which in turns might increase the missing hill as reported of Behera ${ }^{[61]}$. This is because at lower sedimentation period, the majority of the seedlings were not released from the fingers because of the insufficient soil gripping force. Consequently, these seedlings are trapped in the fingers resulting in excessive missing hills. It was also found that throughout the experimental plots hill population increases with the decreased in hill spacing, the seeds quantity of $70 \mathrm{~g}$ seeds per tray decreased from 781 to 517 . The seeds quantity of $240 \mathrm{~g}$ of seeds per tray recorded 3375 reducing to 2250 . However, missing hill is controllable and a function of seedling mat density, uniformity and also hill mortality. Therefore to prevent mortality of hill resulting from snail, mechanical damage, buried and floating hill should be carefully avoided using standard procedures in order to have the optimum plant population. In other words, since the working accuracy of transplanter varies based on the field and seedling conditions, the number of missing hills depended significantly on growing density and uniformity of the seedlings in the mat. The depth of planting and the angle of transplanting were affected primarily by field conditions.

Table 6 Effects of spacing and seed rate treatment on the number of hill population, percentage of missing hills, combined percentage of one and two-seedlings, and the percentage of good seeds

\begin{tabular}{|c|c|c|c|c|c|c|c|c|c|c|c|c|c|c|c|c|}
\hline \multirow{2}{*}{ Block } & \multicolumn{4}{|c|}{ Hill population } & \multicolumn{4}{|c|}{ Percentage of missing hills $/ \%$} & \multicolumn{4}{|c|}{ Percentage of 1 and 2 seedlings/\% } & \multicolumn{4}{|c|}{ Percentage of good seeds/\% } \\
\hline & $\mathrm{S}_{1}$ & $\mathrm{~S}_{2}$ & $\mathrm{~S}_{3}$ & $\mathrm{~S}_{4}$ & $\mathrm{~S}_{1}$ & $\mathrm{~S}_{2}$ & $\mathrm{~S}_{3}$ & $\mathrm{~S}_{4}$ & $\mathrm{~S}_{1}$ & $\mathrm{~S}_{2}$ & $\mathrm{~S}_{3}$ & $\mathrm{~S}_{4}$ & $\mathrm{~S}_{1}$ & $\mathrm{~S}_{2}$ & $\mathrm{~S}_{3}$ & $\mathrm{~S}_{4}$ \\
\hline A & 781 & 689 & 590 & 517 & 0.3 & 1 & 0.4 & 1 & 85 & 74 & 80 & 78 & 80 & 91 & 94 & 95 \\
\hline $\mathrm{B}$ & 781 & 689 & 590 & 517 & 1 & 2.5 & 2 & 2 & 64 & 54 & 63 & 56 & 90 & 89 & 90 & 95 \\
\hline $\mathrm{C}$ & 3375 & 3000 & 2571 & 2250 & 2 & 1 & 2 & 0.4 & 68 & 37 & 50 & 68 & 81 & 88 & 92 & 93 \\
\hline D & 3375 & 3000 & 2571 & 2250 & 1 & 1 & 0.4 & 0 & 64 & 41 & 53 & 16 & 92 & 89 & 93 & 95 \\
\hline
\end{tabular}

A well-prepared field increases the percentage of transplanting time ${ }^{[63]}$, hence the quality of transplanting operation is assessed according to the percentage of missing hills, single, two, three, four and five seedlings. A comparison between the number of empty seeds, percentage of missing hills and number of panicles at different spacing is shown by means of bar plots in Figure 9. The number of seedling per hill influences formation of tiller and reflects nutrient uptake, solar radiation interception, and photosynthesis rate beside other physiological characteristics that affect growth and development of rice. The number of grain-bearing panicles was found to increase with increase in spacing in all the experimental plots (Figure 9), with the $70 \mathrm{~g}$ /tray scattered planting (block B) having the least at $\mathrm{s}_{1}=0.16 \mathrm{~m} \times 0.3 \mathrm{~m}$ spacing, and the $75 \mathrm{~g}$ of seeds/tray scattered planting (block $\mathrm{C}$ ) setting the highest value of 39 grain bearing panicles at $\mathrm{s}_{4}=0.24 \mathrm{~m} \times 0.3 \mathrm{~m}$. These findings are in agreement with the result of literature ${ }^{[64]}$. Aslam et al. ${ }^{[65]}$ reported that transplanted rice increased all the growth and yield attributes of rice over direct seeding. It can be seen that except in block D (240 g/tray), empty seeds decreases with increasing of hill spacing, which may be attributed to more shading of plants, competition for water, nutrients, space and mineral due to the shortage of space. The higher percentage of empty seeds may also be attributed to nutrient deficiency ${ }^{[66]}$. The number of missing hills was found to fluctuate with increasing spacing in all experimental plots as shown in Figure 9 which is similar to the result observed by Behera et al. ${ }^{[61,62]}$. The percentage of missing hill is a function of seedling mat density, uniformity and hill mortality, and fluctuates with increasing hill spacing, i.e., from 2, 5 , 3 , and then 5 in $70 \mathrm{~g} /$ tray with row planting pattern, while in the scattered tray planting pattern it was 7, 22, 15 and 15 . Results showed that the percentage of missing hills in Ladang Sepuluh field was significantly higher than Tanjung Karang experiment, and both were more than the allowable limit of 5\%. Similar results have been reported by Behera et al. ${ }^{[61,62]}$ The working performance of a transplanter was also measured by the time required to transplant a given area. Working time includes the productive (transplanting) and non-productive (time loss in the field). In another study ${ }^{[67]}$ it has been reported that younger seedling has greater ability of producing a higher number of tillers per hill in comparison with older seedlings. Another study ${ }^{[68]}$ suggested that compared to direct seeding, tiller production can be improved by transplanting seedlings at younger ages.

\section{$\square \mathrm{s}_{1}=0.16 \mathrm{~m} \times 0.3 \mathrm{~m} \quad \square \mathrm{s}_{2}=0.18 \mathrm{~m} \times 0.3 \mathrm{~m}$}

\section{$\square \mathrm{s}_{3}=0.21 \mathrm{~m} \times 0.3 \mathrm{~m} \quad \square \mathrm{s}_{4}=0.24 \mathrm{~m} \times 0.3 \mathrm{~m}$}
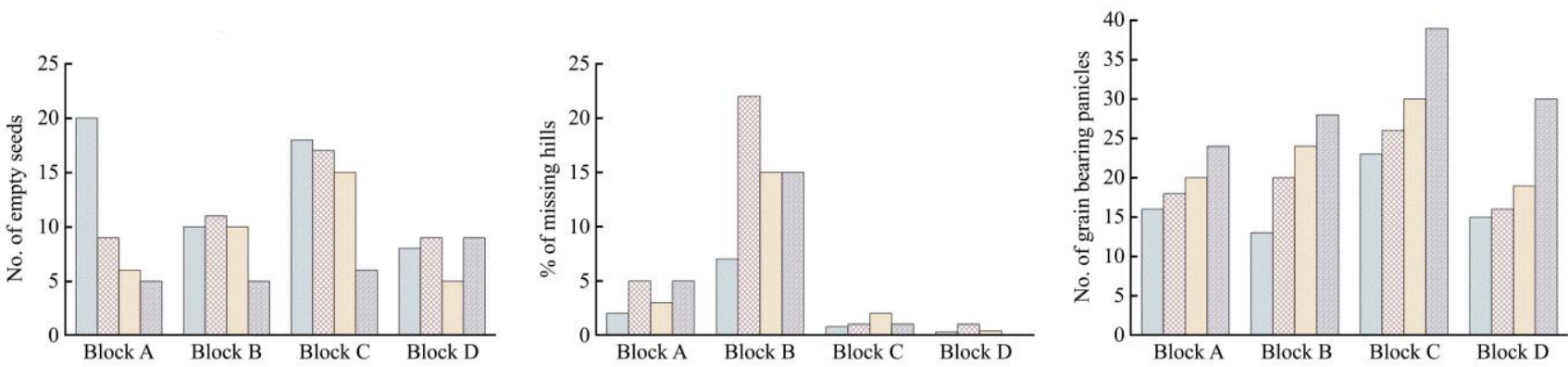

Figure 9 Comparison between percentage of missing hills (left) and number of empty seeds (right) in the four experimental blocks

\subsection{Tiller population}

Tillering influences grain yield because it is closely related to the panicle number produced per unit area of cultivated land ${ }^{[69]}$. The effects of spacing and seed rate treatment on the number of 
transplanted hills, tillers. $\mathrm{m}^{-2}$, tillers per hill, seedlings per hill, and tillers per plant in each experimental block are reported in Table 7. It can be seen that the number of tillers produced per meter square in single seedling was significantly influenced by spacing's. In both treatments (row and scattered) and at the both sites (Ladang Sepuluh and Tanjung Karang), the highest and the lowest number of tillers were recorded from the widest and closest spacing's respectively. The number of tillers at Ladang Sepuluh was however, significantly greater than that of Tanjung Karang, this could probably be due to existing variation in the physico-chemical properties of the soil. Likewise, the number of tillers per meter square in double (two) seedlings is significantly determined by spacing. At Ladang sepuluh, the numbers of tillers per square meter were both $21 \mathrm{~cm}$ and $24 \mathrm{~cm}$ spacings, with both treatments. Similarly, the number of tillers per meter square in both $16 \mathrm{~cm}$ and $18 \mathrm{~cm}$ spacing's were statistically equal under scattered treatment alone. At Tanjung Karang however, similar number of tillers was observed as what was obtained in single seedling. When hills with three seedlings were considered, significant decrease in number of seedlings per meter was observed with increase in spacings regardless of the treatment, however, at Ladang Sepuluh alone, except at $24 \mathrm{~cm}$ spacing under row planting where the number of tillers (420) per square meter was higher. The mean values of number of tillers at Tanjung Karang under three seedlings was statistically similar to what was earlier recorded from single seedling and double seedlings experiments. When four seedlings were considered, both treatments recorded their highest and lowest number of tillers per meter square at $16 \mathrm{~cm}$ and $24 \mathrm{~cm}$ spacings respectively. In all spacings, the row planting treatment had the highest mean tiller value per square meter than the scattered treatment. At Tanjung Karang however, the number of tillers per meter square was similar to what was previously obtained in other considered number of seedlings. When mean tillers number per square meter was considered under five seedlings condition, significance difference was observed. At Ladang Sepuluh, the mean tiller number per meter square was higher in scattered treatment than row at 16 and $18 \mathrm{~cm}$ spacings, the treatments were at par. However, at the widest $24 \mathrm{~cm}$ spacing, row treatment performed significantly better than the scattered. At Tanjung Karang however, the values obtained did not significantly differ with the values that were considered earlier. Generally clear visible differences in the plant morphology and physiological features were observed based on result from the study, the highest productive tillers per hill were recorded for $70 \mathrm{~g}$ row and scattered planting pattern at $24 \mathrm{~cm} \times 30 \mathrm{~cm}$ spacing an average of 65 tillers per hill was observed, while the lowest was recorded at $21 \mathrm{~cm} \times$ $30 \mathrm{~cm}$ spacing. The higher productive tillers. $\mathrm{m}^{-2}$ were attributed to wider spacing and single seedling, as well as the ability for producing many tillers due to less competition for space, sunlight, water, nutrients, mineral and easier management practices. The importance of sufficient of sunlight can be seen clearly on the number of tillers and ears increases with an increase in the intensity and quantity of light. The results are in agreement with those of Tuong et al. ${ }^{[70,71]}$ and Ginigaddara ${ }^{[67]}$ who reported that younger seedling has greater ability of producing a higher number of tillers per hill in comparison with older seedlings. In fact, when seedlings are transplanted precisely at the initial growth stage, the shock of root damage due to uprooting time is minimized, following a rapid growth with short phyllochrons ${ }^{[72]}$. Moreover, rice seedlings transplanted before commencing the fourth phyllochron retained much of their tillering potential ${ }^{[73]}$. Table 7 also shows a higher number of 65 tillers was obtained in the planting spacing of $24 \mathrm{~cm} \times 30 \mathrm{~cm}$, while the lowest number of 15 tillers at a planting spacing of $21 \mathrm{~cm} \times 30 \mathrm{~cm}$, and recorded its highest number of 48 tillers per hill at the spacing of $24 \mathrm{~cm} \times 30 \mathrm{~cm}$, while the least number of 23 tillers was obtained at a planting spacing of $21 \mathrm{~cm} \times 30 \mathrm{~cm}$.

Table 7 Effects of spacing and seed rate treatment on the number of transplanted hills, tillers $/ \mathrm{m}^{2}$, tillers $/ \mathrm{hill}$, seedlings/hill, and tillers/plant in Ladang Sepuluh experiment (block A: row mat, block B: scattered mat) and in Tanjung Karang experiment (block C: 75 g/tray, block D: 240 g/tray)

\begin{tabular}{|c|c|c|c|c|c|c|c|c|c|c|c|c|c|c|c|c|c|c|c|c|}
\hline \multirow{3}{*}{$\begin{array}{l}\text { Spacing } \\
/ \mathrm{m}\end{array}$} & \multicolumn{5}{|c|}{ Block A } & \multicolumn{5}{|c|}{ Block B } & \multicolumn{5}{|c|}{ Block C } & \multicolumn{5}{|c|}{ Block D } \\
\hline & $1 \mathrm{~S}$ & $2 \mathrm{~S}$ & $3 \mathrm{~S}$ & $4 \mathrm{~S}$ & $5 \mathrm{~S}$ & $1 \mathrm{~S}$ & $2 \mathrm{~S}$ & $3 \mathrm{~S}$ & $4 \mathrm{~S}$ & $5 S$ & $1 \mathrm{~S}$ & $2 S$ & $3 \mathrm{~S}$ & $4 \mathrm{~S}$ & $5 S$ & $1 \mathrm{~S}$ & $2 \mathrm{~S}$ & $3 \mathrm{~S}$ & $4 \mathrm{~S}$ & $5 \mathrm{~S}$ \\
\hline & \multicolumn{20}{|c|}{ No. of transplanted hills (Number of seedlings/hill) } \\
\hline 0.16 & 484 & 180 & 62 & 39 & 16 & 351 & 148 & 203 & 55 & 23 & 1205 & 1080 & 675 & 270 & 135 & 810 & 1350 & 911 & 2362 & 34 \\
\hline 0.18 & 345 & 165 & 76 & 69 & 34 & 234 & 138 & 220 & 90 & 14 & 594 & 504 & 1039 & 534 & 297 & 720 & 510 & 900 & 300 & 570 \\
\hline 0.21 & 201 & 271 & 88 & 18 & 12 & 136 & 236 & 159 & 35 & 24 & 720 & 566 & 423 & 514 & 308 & 540 & 823 & 463 & 514 & 231 \\
\hline \multirow[t]{2}{*}{0.24} & 238 & 165 & 26 & 52 & 36 & 181 & 109 & 165 & 41 & 21 & 810 & 720 & 450 & 180 & 90 & 225 & 135 & 270 & 900 & 720 \\
\hline & \multicolumn{20}{|c|}{ Number of tillers/m } \\
\hline 0.16 & 588 & 630 & 546 & 420 & 168 & 420 & 420 & 378 & 252 & 210 & 483 & 441 & 525 & 420 & 567 & 441 & 462 & 420 & 483 & 490 \\
\hline 0.18 & 722 & 570 & 532 & 399 & 154 & 532 & 380 & 380 & 323 & 266 & 361 & 342 & 380 & 304 & 494 & 380 & 399 & 399 & 380 & 494 \\
\hline 0.21 & 736 & 512 & 416 & 320 & 96 & 960 & 512 & 336 & 128 & 96 & 288 & 240 & 304 & 336 & 447 & 256 & 272 & 272 & 304 & 480 \\
\hline \multirow[t]{2}{*}{0.24} & 910 & 532 & 420 & 392 & 294 & 910 & 532 & 294 & 280 & 252 & 910 & 840 & 700 & 630 & 602 & 714 & 672 & 630 & 490 & 546 \\
\hline & \multicolumn{20}{|c|}{ Number of tillers/hill (Number of tillers/plant) } \\
\hline 0.16 & 28 & 30 & 26 & 20 & 8 & 20 & 20 & 18 & 12 & 10 & 23 & 21 & 25 & 20 & 27 & 21 & 22 & 20 & 23 & 23 \\
\hline 0.18 & 38 & 30 & 28 & 21 & 8 & 28 & 20 & 20 & 17 & 14 & 19 & 18 & 20 & 16 & 26 & 20 & 21 & 21 & 20 & 26 \\
\hline 0.21 & 46 & 32 & 26 & 20 & 6 & 60 & 32 & 21 & 8 & 6 & 18 & 15 & 19 & 21 & 28 & 16 & 17 & 17 & 19 & 30 \\
\hline 0.24 & 65 & 38 & 30 & 28 & 21 & 65 & 38 & 21 & 20 & 18 & 65 & 60 & 50 & 45 & 43 & 51 & 48 & 45 & 35 & 39 \\
\hline
\end{tabular}

\subsection{Seedling count}

Different numbers of seedlings per hill and tillers per hill were observed due to different planting spacing and pattern Table 8 and planting spacing and seed density Table 9. It can be seen that the number of seedlings per hill varies with inter hill spacing in all treatments while the width of planting is fixed at $30 \mathrm{~cm}$ apart, a 
function of the transplanter parameter. A varied proportion was observed and recorded as shown in Table 8 in Blocks A and B using $70 \mathrm{~g}$ of seeds per tray at Ladang Sepuluh. The results indicated that spacing had significant effect on the number of single seedling establishment per hill regardless of planting pattern. In both the scattered and row planting patterns, the highest and the least number of single seedling per hill were obtained from spacings of $16 \mathrm{~cm} \times 30 \mathrm{~cm}$ and $2 \mathrm{~cm} \times 30 \mathrm{~cm}$ respectively. Likewise, plant spacings had significant effect on the number of two seedlings establishment per hill. In both planting patterns $21 \mathrm{~cm} \times 30 \mathrm{~cm}$ spacing had the highest number of two seedlings establishment per hill. Similarly $24 \mathrm{~cm} \times 30 \mathrm{~cm}$ recorded the least number of two seedlings establishment per hill. In the scattered planting pattern, $24 \mathrm{~cm} \times 30 \mathrm{~cm}$ and $18 \mathrm{~cm} \times 30 \mathrm{~cm}$ were numerically equal and statistically at par. Also spacing had significant effect on the number of three seedlings establishment per hill in both planting patterns. In the scattered planting pattern $21 \mathrm{~cm} \times 30 \mathrm{~cm}$ and $24 \mathrm{~cm} \times 30 \mathrm{~cm}$ spacings recorded the highest as well as the lowest number of three seedlings establishment per hill. Respectively in the row planting pattern however, $18 \mathrm{~cm} \times 30 \mathrm{~cm}$ and $21 \mathrm{~cm} \times 30 \mathrm{~cm}$ spacings recorded the highest and the lowest number of three seedlings establishment per hill.

Table 8 Comparison of mean effect of plant spacing and planting pattern on number of seedlings per hill and number of tillers per hill in Ladang Sepuluh experiment (block A: row mat, block B: scattered mat)

\begin{tabular}{|c|c|c|c|c|c|c|c|c|c|c|c|c|c|c|c|c|c|c|c|c|c|}
\hline \multirow{2}{*}{\multicolumn{2}{|c|}{ Seedlings per hill }} & \multicolumn{4}{|c|}{ One seedling } & \multicolumn{4}{|c|}{ Two seedling } & \multicolumn{4}{|c|}{ Three seedling } & \multicolumn{4}{|c|}{ Four seedling } & \multicolumn{4}{|c|}{ Five seedling } \\
\hline & & $\mathrm{s}_{1}$ & $\mathrm{~s}_{2}$ & $\mathrm{~s}_{3}$ & $\mathrm{~S}_{4}$ & $\mathrm{~s}_{1}$ & $\mathrm{~s}_{2}$ & $\mathrm{~s}_{3}$ & $\mathrm{~s}_{4}$ & $\mathrm{~s}_{1}$ & $\mathrm{~s}_{2}$ & $\mathrm{~s}_{3}$ & $\mathrm{~s}_{4}$ & $\mathrm{~s}_{1}$ & $\mathrm{~s}_{2}$ & $\mathrm{~s}_{3}$ & $\mathrm{~s}_{4}$ & $\mathrm{~s}_{1}$ & $\mathrm{~s}_{2}$ & $\mathrm{~s}_{3}$ & $\mathrm{~S}_{4}$ \\
\hline \multirow{3}{*}{ Row mat } & $\mathrm{A}_{1}$ & 53 & 37 & 22 & 28 & 20 & 19 & 31 & 18 & 7 & 8 & 9 & 3 & 4 & 9 & 2 & 5 & 2 & 5 & 1 & 4 \\
\hline & $\mathrm{A}_{2}$ & 54 & 36 & 23 & 26 & 19 & 17 & 30 & 19 & 8 & 9 & 10 & 2 & 5 & 7 & 2 & 6 & 1 & 3 & 1 & 5 \\
\hline & $\mathrm{A}_{3}$ & 52 & 38 & 24 & 27 & 21 & 18 & 32 & 20 & 6 & 7 & 11 & 4 & 3 & 8 & 2 & 7 & 3 & 4 & 1 & 3 \\
\hline \multirow[t]{2}{*}{ Mean } & & 53 & 37 & 23 & 27 & 20 & 18 & 31 & 19 & 7 & 8 & 10 & 3 & 4 & 8 & 2 & 6 & 2 & 4 & 1 & 4 \\
\hline & $\mathrm{B}_{1}$ & 37 & 20 & 14 & 20 & 15 & 12 & 23 & 10 & 21 & 19 & 17 & 18 & 6 & 8 & 5 & 3 & 2 & 1 & 3 & 3 \\
\hline \multirow[t]{2}{*}{ Scattered } & $\mathrm{B}_{2}$ & 38 & 21 & 13 & 18 & 17 & 13 & 24 & 12 & 22 & 20 & 16 & 17 & 7 & 7 & 3 & 4 & 3 & 0 & 2 & 1 \\
\hline & $\mathrm{B}_{3}$ & 36 & 22 & 12 & 19 & 16 & 11 & 22 & 11 & 20 & 21 & 15 & 16 & 5 & 9 & 4 & 5 & 1 & 2 & 1 & 2 \\
\hline Mean & & 37 & 21 & 13 & 19 & 16 & 12 & 23 & 11 & 21 & 20 & 16 & 17 & 6 & 8 & 4 & 4 & 2 & 1 & 2 & 2 \\
\hline \multicolumn{22}{|c|}{ Tillers per hill } \\
\hline \multirow{3}{*}{ Row mat } & $\mathrm{A}_{1}$ & 29 & 38 & 46 & 66 & 30 & 34 & 36 & 38 & 26 & 30 & 32 & 34 & 20 & 22 & 20 & 28 & 8 & 6 & 7 & 20 \\
\hline & $\mathrm{A}_{2}$ & 28 & 37 & 47 & 65 & 32 & 33 & 34 & 36 & 27 & 28 & 26 & 29 & 19 & 20 & 19 & 29 & 7 & 9 & 5 & 22 \\
\hline & $\mathrm{A}_{3}$ & 27 & 39 & 45 & 64 & 28 & 30 & 31 & 34 & 28 & 27 & 25 & 30 & 21 & 21 & 21 & 27 & 9 & 9 & 6 & 21 \\
\hline \multirow[t]{2}{*}{ Mean } & & 28 & 38 & 46 & 65 & 30 & 32 & 33 & 36 & 27 & 28 & 27 & 31 & 20 & 21 & 20 & 28 & 8 & 8 & 6 & 21 \\
\hline & $\mathrm{B}_{1}$ & 19 & 27 & 60 & 67 & 19 & 20 & 31 & 38 & 19 & 20 & 20 & 16 & 12 & 17 & 9 & 19 & 10 & 14 & 6 & 18 \\
\hline \multirow[t]{2}{*}{ Scattered } & $\mathrm{B}_{2}$ & 21 & 28 & 58 & 64 & 20 & 21 & 33 & 37 & 18 & 19 & 19 & 18 & 13 & 16 & 7 & 21 & 9 & 15 & 5 & 17 \\
\hline & $\mathrm{B}_{3}$ & 20 & 29 & 62 & 64 & 21 & 19 & 32 & 39 & 17 & 21 & 23 & 17 & 11 & 18 & 8 & 20 & 11 & 13 & 7 & 19 \\
\hline Mean & & 29 & 38 & 46 & 66 & 30 & 34 & 36 & 38 & 26 & 30 & 32 & 34 & 20 & 22 & 20 & 28 & 8 & 6 & 7 & 20 \\
\hline
\end{tabular}

Table 9 Comparison of mean effect of plant spacing and seed rate per tray on number of seedlings per hill and number of tillers per hill in Tanjung Karang experiment (block C: 75 g/tray, block D: 240 g/tray)

\begin{tabular}{|c|c|c|c|c|c|c|c|c|c|c|c|c|c|c|c|c|c|c|c|c|c|}
\hline \multirow{2}{*}{\multicolumn{2}{|c|}{ Seedlings per hill }} & \multicolumn{4}{|c|}{ One seedling } & \multicolumn{4}{|c|}{ Two seedling } & \multicolumn{4}{|c|}{ Three seedling } & \multicolumn{4}{|c|}{ Four seedling } & \multicolumn{4}{|c|}{ Five seedling } \\
\hline & & $\mathrm{s}_{1}$ & $\mathrm{~s}_{2}$ & $\mathrm{~s}_{3}$ & $\mathrm{~s}_{4}$ & $\mathrm{~s}_{1}$ & $\mathrm{~s}_{2}$ & $\mathrm{~s}_{3}$ & $\mathrm{~s}_{4}$ & $\mathrm{~s}_{1}$ & $\mathrm{~s}_{2}$ & $\mathrm{~s}_{3}$ & $\mathrm{~s}_{4}$ & $\mathrm{~s}_{1}$ & $\mathrm{~s}_{2}$ & $\mathrm{~s}_{3}$ & $\mathrm{~s}_{4}$ & $\mathrm{~s}_{1}$ & $\mathrm{~s}_{2}$ & $\mathrm{~s}_{3}$ & $\mathrm{~s}_{4}$ \\
\hline \multirow{3}{*}{$75 \mathrm{~g}$} & $\mathrm{C}_{1}$ & 2573 & 594 & 736 & 717 & 2287 & 505 & 579 & 637 & 1430 & 1039 & 473 & 398 & 573 & 535 & 527 & 159 & 286 & 298 & 315 & 81 \\
\hline & $\mathrm{C}_{2}$ & 2572 & 595 & 737 & 716 & 2286 & 503 & 578 & 636 & 1429 & 1040 & 734 & 399 & 570 & 534 & 526 & 160 & 287 & 296 & 317 & 80 \\
\hline & $\mathrm{C}_{3}$ & 2571 & 593 & 735 & 715 & 2285 & 504 & 580 & 638 & 1428 & 1038 & 732 & 397 & 573 & 353 & 525 & 158 & 285 & 296 & 316 & 79 \\
\hline \multirow[t]{2}{*}{ Mean } & & 2572 & 594 & 736 & 716 & 2286 & 504 & 579 & 637 & 1429 & 1039 & 646 & 398 & 572 & 474 & 526 & 159 & 286 & 296 & 316 & 80 \\
\hline & $\mathrm{D}_{1}$ & 1753 & 717 & 560 & 201 & 2863 & 508 & 852 & 120 & 1941 & 895 & 479 & 240 & 501 & 299 & 533 & 801 & 104 & 570 & 238 & 641 \\
\hline \multirow[t]{2}{*}{$240 \mathrm{~g}$} & $\mathrm{D}_{2}$ & 1751 & 715 & 559 & 200 & 2862 & 506 & 851 & 121 & 1943 & 897 & 480 & 241 & 500 & 300 & 531 & 799 & 106 & 568 & 240 & 640 \\
\hline & $\mathrm{D}_{3}$ & 1752 & 716 & 558 & 199 & 2861 & 507 & 850 & 199 & 1942 & 896 & 478 & 239 & 502 & 298 & 532 & 800 & 102 & 569 & 239 & 639 \\
\hline Mean & & 1752 & 716 & 559 & 200 & 2862 & 507 & 851 & 146 & 1942 & 896 & 479 & 240 & 501 & 299 & 532 & 800 & 104 & 569 & 239 & 640 \\
\hline \multicolumn{22}{|c|}{ Tillers per hill } \\
\hline \multirow{3}{*}{$75 \mathrm{~g}$} & $\mathrm{C}_{1}$ & 27 & 29 & 27 & 43 & 27 & 27 & 27 & 42 & 27 & 28 & 28 & 44 & 28 & 27 & 29 & 16 & 25 & 27 & 29 & 16 \\
\hline & $\mathrm{C}_{2}$ & 26 & 28 & 29 & 44 & 25 & 25 & 29 & 44 & 25 & 27 & 29 & 44 & 28 & 25 & 29 & 44 & 26 & 25 & 29 & 44 \\
\hline & $\mathrm{C}_{3}$ & 28 & 27 & 28 & 42 & 26 & 28 & 28 & 44 & 28 & 29 & 28 & 43 & 27 & 27 & 28 & 42 & 28 & 27 & 28 & 42 \\
\hline \multirow[t]{2}{*}{ Mean } & & 27 & 28 & 28 & 43 & 26 & 26 & 28 & 43 & 26 & 28 & 28 & 43 & 27 & 26 & 287 & 34 & 26 & 26 & 28 & 34 \\
\hline & $\mathrm{D}_{1}$ & 24 & 28 & 30 & 40 & 23 & 26 & 30 & 42 & 22 & 28 & 29 & 40 & 21 & 27 & 30 & 38 & 20 & 25 & 30 & 40 \\
\hline \multirow[t]{2}{*}{$240 \mathrm{~g}$} & $\mathrm{D}_{2}$ & 25 & 27 & 32 & 39 & 24 & 25 & 33 & 40 & 23 & 27 & 32 & 39 & 22 & 25 & 29 & 39 & 19 & 27 & 32 & 39 \\
\hline & $\mathrm{D}_{3}$ & 26 & 26 & 29 & 38 & 23 & 27 & 29 & 38 & 20 & 29 & 32 & 38 & 19 & 27 & 30 & 40 & 20 & 25 & 29 & 38 \\
\hline Mean & & 25 & 27 & 30 & 39 & 23 & 26 & 30 & 40 & 21 & 28 & 31 & 39 & 20 & 26 & 29 & 39 & 19 & 25 & 30 & 39 \\
\hline
\end{tabular}

For a fixed planting space, the number of seedlings per hill were found to change with inter-hill spacing in all blocks treatments. The effect of seed rate on the number of established seedlings per hill was found to be significant in plots with single 
and three seedlings per hill ( $p$-values reported in Table 10); however, plots that had two, four and five seedlings per hill were not significantly influenced by seeding rate. Effects of plant spacing on averaged numbers of seedling per hill and tillers per hill in different experimental blocks are shown by means of bar plots in Figure 10. At both $70 \mathrm{~g}$ and $75 \mathrm{~g}$ seeding rates (block A and C), plots with single and two seedlings per hill had the highest number of seedling establishment that differed significantly with plots that had four and five seedlings per hill. This can be explained as the high lodging competition between the plants in dense fields, sometimes resulting gradual shading that decreases grain formation in favor of straw production. At a fixed spacing, the highest and least numbers of seedlings were respectively observed in plots with two and five seedling per hill. Plant spacing was found to have no significant effect on the number of seedling establishment per hill throughout the experiment. The highest productive tillers per square meter were recorded for $70 \mathrm{~g} /$ tray seed with row and scattered planting pattern at $\mathrm{s}_{4}=0.24 \mathrm{~m} \times 0.3 \mathrm{~m}$ spacing (Figure 10) with an average of 65 tillers per stand, while the lowest was recorded at $\mathrm{s}_{3}=0.21 \mathrm{~m} \times 0.3 \mathrm{~m}$ spacing. This is also consistent with the findings of Faruk et al. ${ }^{[74]}$ who reported that all yield parameters except 1000-grain weight and panicle length was influenced by the number of seedling per hill. It can be concluded that the lowest number of bearing tillers and grains panicle per hill results the lowest grain and straw yield, while the highest number of non-bearing tillers per hill are resulted from single seedling per hill.

Table $10 p$-values corresponding to the two-way ANOVA tests in each experiment

\begin{tabular}{|c|c|c|c|c|c|c|c|c|c|c|c|}
\hline \multirow{2}{*}{ Source } & \multirow{2}{*}{ df } & \multicolumn{5}{|c|}{$p$-value for variation in seedling/hill } & \multicolumn{5}{|c|}{$p$-value for variation in tillers/hill } \\
\hline & & $\begin{array}{c}\text { One } \\
\text { seedling }\end{array}$ & $\begin{array}{c}\text { Two } \\
\text { seedling }\end{array}$ & $\begin{array}{c}\text { Three } \\
\text { seedling }\end{array}$ & $\begin{array}{c}\text { Four } \\
\text { seedling }\end{array}$ & $\begin{array}{c}\text { Five } \\
\text { seedling }\end{array}$ & $\begin{array}{c}\text { One } \\
\text { seedling }\end{array}$ & $\begin{array}{c}\text { Two } \\
\text { seedling }\end{array}$ & $\begin{array}{c}\text { Three } \\
\text { seedling }\end{array}$ & $\begin{array}{c}\text { Four } \\
\text { seedling }\end{array}$ & $\begin{array}{c}\text { Five } \\
\text { seedling }\end{array}$ \\
\hline Spacing & 3 & 0.0000 & 0.0000 & 0.0000 & 0.0000 & 0.0698 & 0.0000 & 0.0000 & 0.4257 & 0.0000 & 0.0000 \\
\hline Pattern & 1 & 0.0000 & 0.0000 & 0.0000 & 0.2089 & 0.0186 & 0.0727 & 0.0000 & 0.0000 & 0.0000 & 0.0146 \\
\hline Interaction & 3 & 0.0000 & 0.0086 & 0.0000 & 0.0051 & 0.0074 & 0.0000 & 0.0000 & 0.0397 & 0.0000 & 0.0000 \\
\hline Seed rate & 1 & 0.0000 & 0.0000 & 0.6134 & 0.0000 & 0.0000 & 0.0176 & 0.0959 & 0.0024 & 0.9143 & 0.9430 \\
\hline Interaction & 3 & 0.0000 & 0.0000 & 0.0000 & 0.0000 & 0.0000 & 0.0010 & 0.0076 & 0.0001 & 0.3446 & 0.3603 \\
\hline
\end{tabular}
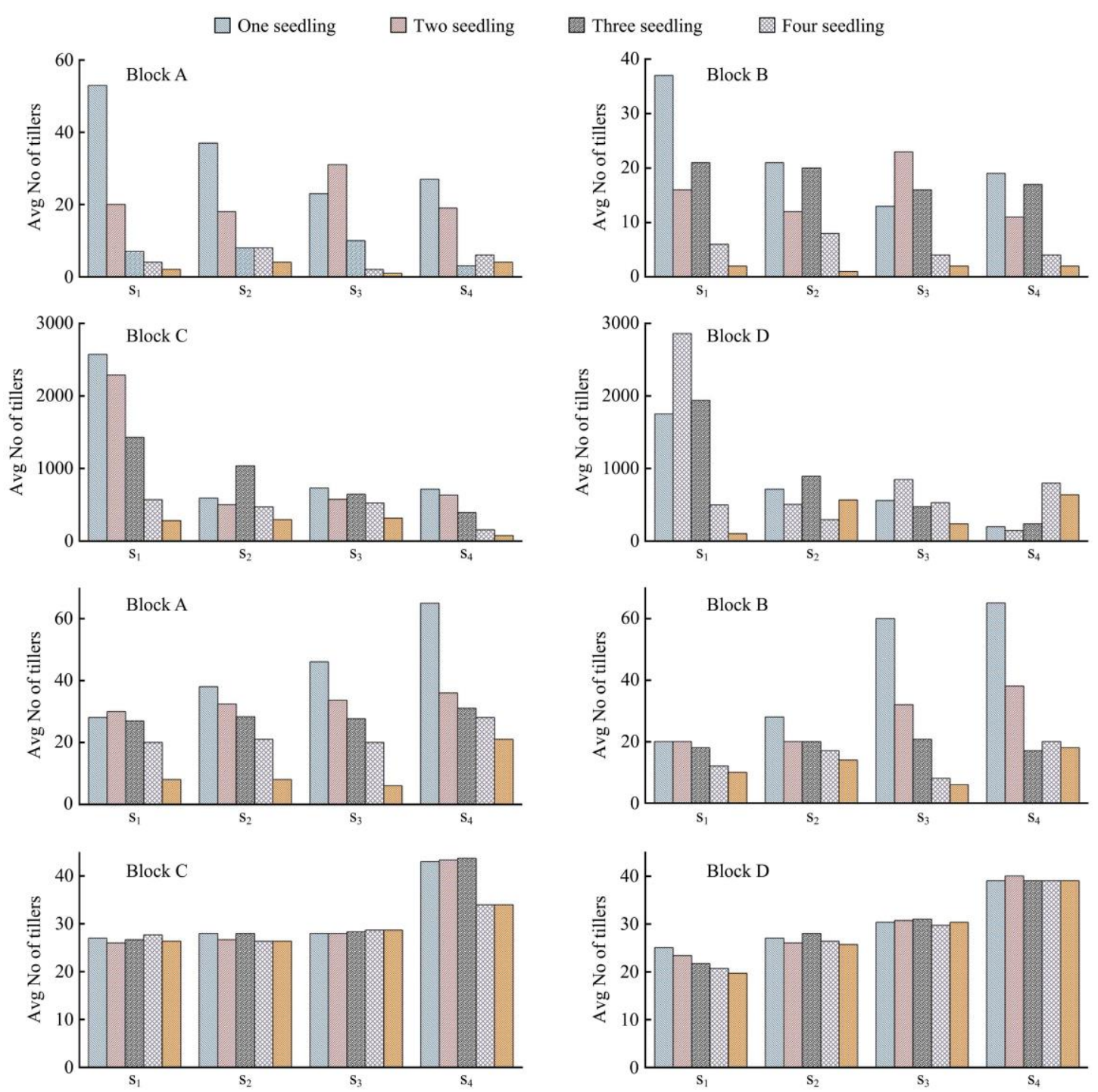

Figure 10 Effects of plant spacing on averaged numbers of seedling per hill and tillers per hill in different experimental blocks 


\subsection{Yield and yield component data}

The yield and yield related parameter components of the rice crop harvested recorded at harvest time are given in Table 11 and Table 12. In these tables, $Y t$ stands for the total seed yield $\left(\mathrm{t} / \mathrm{hm}^{2}\right)$, $Y g$ is the yield of good sees $\left(\mathrm{t} / \mathrm{hm}^{2}\right)$, and $Y e$ is the yield of empty grains $\left(\mathrm{t} / \mathrm{hm}^{2}\right)$. The highest and lowest yields were obtained from $75 \mathrm{~g}$ seeds per tray scattered and $70 \mathrm{~g}$ seeds per tray scattered treatment respectively. For all spacings treatments the result clearly indicate increase in yield with increase in spacing (Figure 11). While the yield of $75 \mathrm{~g}$ seeds per tray scattered treatment was found to be higher than that of $240 \mathrm{~g}$ seeds per tray scattered treatment but the difference was not statistically significant. The yield performance of $70 \mathrm{~g}$ seeds per tray scattered treatment was significantly higher than that of $70 \mathrm{~g}$ seeds per tray row in all the spacings. It is also noticeable that the performance of $70 \mathrm{~g}$ seeds per tray row spacing at widest spacing $24 \mathrm{~cm} \times 30 \mathrm{~cm}$ was at par with $75 \mathrm{~g}$ seeds per tray scattered and $240 \mathrm{~g}$ seeds per tray treatments when at the closest $16 \mathrm{~cm} \times 30 \mathrm{~cm}$ spacing (Table 12). This can be explained by the fact that the highest number of tillers is inversely proportional to the length of the phyllochron ${ }^{[6,54]}$, which is reliant on the extent of stresses. Moreover, wider spacing, abundant light, medium temperature and soil aeration, as well as good nutrient supply encourage shorter phyllochrons which increase the number of tillers ${ }^{[36,54]}$. In addition, transplanting impose a certain degree of stress by which the rate of phyllochron development would be depressed ${ }^{[72]}$. In contrast, the absence of transplanting shock with 7-21 d old seedlings has been reported ${ }^{[68]}$. The good performance of rice cultivation under the name of SRI may be seen through the higher number of tillers per hill, grains per panicles, the percentage of good seeds compared with empty and lastly the output per hectare. Our findings confirm previous reports ${ }^{[54,71,75,76]}$ that by changing the management practices, increase in yield under SRI practice has been noted. The transplanting of young seedlings plays a great role in earlier crop establishment through the avoidance and minimization of transplanting shock, thus resulting in higher grain yield by allowing the plant to complete greater phyllochrons before onset of anthesis $^{[71]}$. As mentioned earlier, wider spacing helps in reducing inter plant competition for air, water, nutrients and sunlight. While the higher percentage of empty seeds may be attributed to competition among the less spaced plant for space and nutrients as reported by Thomas et al. ${ }^{[66]}$, our study suggests that planting density in rice crop play an important role for dry matter and grain yield. The optimum level of plant population together with better yield parameters (i.e. sufficient sunlight for photosynthesis, water, nutrients) have resulted in higher seed yield per hectare with $24 \mathrm{~cm} \times 30 \mathrm{~cm}$ spacing using $70 \mathrm{~g} /$ tray row planting pattern. These findings are consistence with findings of Ceesay et al. ${ }^{[75,77]}$.

Table 11 Effects of spacing and seed rate treatment on yield component in Ladang Sepuluh experiment (block A: row mat, block B: scattered mat). $\quad Y_{t}$ : Total seed yield $\left(\mathrm{t} / \mathrm{hm}^{2}\right), Y_{g}$ : Yield of good sees $\left(\mathrm{t} / \mathrm{hm}^{2}\right), Y_{e}:$ Yield of empty grains $\left(\mathrm{t} / \mathrm{hm}^{2}\right)$

\begin{tabular}{|c|c|c|c|c|c|c|c|c|c|}
\hline \multirow{2}{*}{ Spacing/m } & \multirow{2}{*}{ Number of seedling } & \multicolumn{4}{|c|}{ Block A } & \multicolumn{4}{|c|}{ Block B } \\
\hline & & No. of gains/panicle & $Y_{t}$ & $Y_{g}$ & $Y_{e}$ & No. of gains/panicle & $Y_{t}$ & $Y_{g}$ & $Y_{e}$ \\
\hline \multirow{5}{*}{0.16} & One seedling & 17 & 7 & 5.6 & 1.4 & 13 & 7.2 & 6.2 & 1 \\
\hline & Two seedling & 15 & 6.8 & 5.4 & 1.1 & 13 & 6.6 & 5.2 & 1.4 \\
\hline & Three seedling & 12 & 6.4 & 5.9 & 1.2 & 11 & 4.2 & 2.6 & 1.6 \\
\hline & Four seedling & 12 & 6 & 5.4 & 1.1 & 12 & 3.6 & 2.2 & 1.4 \\
\hline & Five seedling & 10 & 5.6 & 4.2 & 1.9 & 10 & 2.8 & 1.1 & 1.3 \\
\hline \multirow{5}{*}{0.18} & One seedling & 25 & 8.2 & 7.4 & 0.8 & 20 & 5.7 & 5.1 & 0.6 \\
\hline & Two seedling & 28 & 8 & 7.4 & 0.6 & 18 & 5.3 & 4.7 & 0.6 \\
\hline & Three seedling & 24 & 7.6 & 5.6 & 2 & 18 & 4.2 & 3.2 & 1 \\
\hline & Four seedling & 19 & 6 & 5.1 & 2.4 & 14 & 3.8 & 2.4 & 1.4 \\
\hline & Five seedling & 17 & 5.6 & 5.3 & 0.3 & 10 & 3.6 & 2.6 & 1 \\
\hline \multirow{4}{*}{0.21} & One seedling & 28 & 8.2 & 7.6 & 0.6 & 24 & 6 & 5.4 & 0.6 \\
\hline & Three seedling & 24 & 7.6 & 6.7 & 0.9 & 16 & 4 & 3.2 & 0.8 \\
\hline & Four seedling & 22 & 6.8 & 5.8 & 1 & 14 & 3.8 & 2.8 & 1 \\
\hline & Five seedling & 20 & 3.8 & 2.3 & 1.5 & 10 & 3.2 & 2.4 & 0.8 \\
\hline \multirow{5}{*}{0.24} & One seedling & 28 & 8.6 & 8.2 & 0.4 & 28 & 7.5 & 7 & 0.5 \\
\hline & Two seedling & 24 & 8.2 & 7.8 & 0.4 & 25 & 6.6 & 6 & 0.6 \\
\hline & Three seedling & 20 & 8 & 7.5 & 0.5 & 22 & 4.2 & 3.8 & 0.4 \\
\hline & Four seedling & 18 & 7.2 & 6.8 & 0.4 & 22 & 3.6 & 2.6 & 1 \\
\hline & Five seedling & 16 & 6.2 & 5.9 & 0.3 & 19 & 2.8 & 2 & 0.8 \\
\hline
\end{tabular}

Table 12 Effects of spacing and seed rate treatment on the yield component in Tanjung Karang experiment (block C: 75 g/tray, block D: 240 g/tray)

\begin{tabular}{|c|c|c|c|c|c|c|c|c|c|}
\hline & Spacing/m & No. of plants & No. of grains/panicles & Moisture content $/ \%$ & Temperature & Total harvested rice $/ \mathrm{kg}$ & $Y_{t}$ & $Y_{g}$ & $Y_{e}$ \\
\hline \multirow{3}{*}{ Block C } & 0.16 & 3375 & 18 & 27.3 & 37.4 & 41 & 7.6 & 6.2 & 1.4 \\
\hline & 0.18 & 3000 & 18 & 27.6 & 37.2 & 42 & 8.6 & 7.6 & 1 \\
\hline & 0.24 & 2250 & 34 & 32.2 & 34.6 & 45 & 9.3 & 8.7 & 0.6 \\
\hline \multirow{3}{*}{ Block D } & 0.16 & 3375 & 15 & 27.5 & 33.2 & 38.4 & 7.5 & 6.9 & 0.6 \\
\hline & 0.18 & 3000 & 16 & 29.1 & 34.1 & 39 & 8 & 7.1 & 0.9 \\
\hline & 0.24 & 2250 & 30 & 27.9 & 33.2 & 46 & 9.1 & 8.6 & 0.5 \\
\hline
\end{tabular}




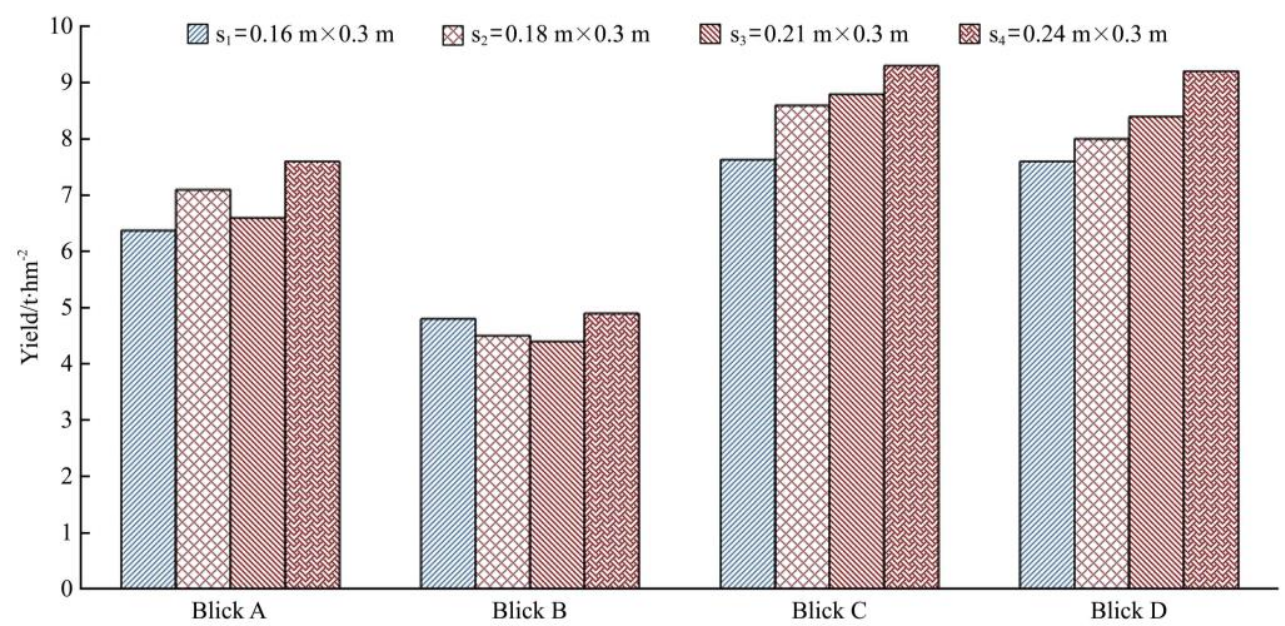

Figure 11 Summary of the effect of spacing and seed rate treatment on yield data $\left(\mathrm{t} / \mathrm{hm}^{2}\right)$ in Ladang Sepuluh experiment (block A: row mat, block B: scattered mat) and Tanjung Karang experiment (block C: 75 g/tray, block D: 240 g/tray)

\subsection{Germination count for improving plant establishment}

Germination count was done to determine the suitability of the planting medium in relation to the growth and development of the rice seedling and its easiness in single removal. It was found that selected seeds soaked in distilled water had 99\% germination potential; therefore they can be adopted in order to avoid missing hills during transplanting operation. Physical properties of $14 \mathrm{~d}$ SRI seedling showed that on the average, the transplanted seedling contained 2-3 numbers of leaves, stem thickness of $2 \mathrm{~mm}$, stem length of $19 \mathrm{~mm}$ and root length of $3.5 \mathrm{~mm}$. Transplanting depth was measured and found to have a mean value of $3 \mathrm{~mm}$. No significant difference was observed in the depth of transplanting among all the treatments due to the homogeneity of the soil throughout the two sites and equally receiving of land preparation practices. It was also found that the transplanter performance depended on seedling quality as well as the quality of the seedling mat media on which the seedlings were raised. It should be noted that seedling quality index is a factor of age, leaf stage, thickness at base high, growing density and lateral root length, while mat quality is a factor of media type, rapture strength, composition, moisture content and the degree of root entanglement.

One potential way of improving plant establishment is to develop seed treatments that can increase seed vigor or germination rates. The most common method employed is the seed priming. Seed priming is a controlled hydration process followed by re-drying that allows the seeds to imbibe water and begin the internal biological processes necessary for seed germination, but which also does not allow the seed to actually germinate. The priming process gives the seed what is called "head-start" at germination and emergence when planted in the soil. The method of priming as reported by Farooq et al. ${ }^{[78]}$ aids in the improvement function of seeds as well as increasing quality of seeds at unfavorable environmental conditions. It is also reported that seeds priming improves seed germination in a range of environmental stresses, i.e. drought, salinity and temperature ${ }^{[79,80]}$. It should be noted that transplanting of young seedlings plays an important role in faster crop establishment by minimizing the transplanting shock, thus resulting in higher grain yield ${ }^{[71]}$.

\section{Conclusions and future work}

This research provided a technical examination of the impacts of alternative transplanting approaches using a controlled experimental design in university-managed rice study plots at two sites in Malaysia. The goal of the paper was to inform good practices for the implementation of SRI-based rice cultivation practices using machine-based planting with alternative configurations. For this purpose we first provided a short review on how system of rice intensification contributes to producing higher rice yield with improved transplanting practices as well as producing a more effective root system. Field experiments were carried out to determine the effect of different seedling rates on various spacings $(14 \mathrm{~cm}, 16 \mathrm{~cm}, 18 \mathrm{~cm}, 21 \mathrm{~cm}$ and $24 \mathrm{~cm})$ on the performance of modified planting finger to single and double seedlings planting, using gear shift of position 3 . The spacings were based on the Kubota SPU 68C transplanter settings. It was concluded that the transplanter performance was dependent on seedling quality as well as the quality of the seedling mat media on which the seedlings are raised. This can only be achieved through good seed selection to avoid missing hills and a good quality of rice husk that allows better distribution of roots. The research also introduces a new row planting pattern aimed at reducing seed rate requirements on the performance of the modified transplanter finger, with the overall aim of meeting the requirements of SRI guidelines in transplanting operation. It was found that over $70 \%$ of seeds could be saved, through reducing the plant population at same time boost plant performance and yield. Before the development of the planting finger, the physical properties of the MR219 rice seedling variety, commonly grown in Malaysia was determined i.e. stem thickness and root length and previous literatures to appropriate come-up with $9 \mathrm{~mm}$ planting finger. The row planting pattern tray was design to provide seedlings in a row mat for planting in paddy fields, best achieved through seeds cleaning and sorting. Statistical analysis showed the efficiency of the planting finger in SRI seedling planting requirement was at $75 \mathrm{~g}$ seeds/tray as the best option for the farmers. It was also concluded that $75 \mathrm{~g}$ seeds/tray manifested better in providing higher yield per hectare when compared to other treatments. This means farmers can conveniently use the modified planting finger SPU 68C Kubota transplanter for their field work to enhance their productivity from $3.7 \mathrm{t} / \mathrm{hm}^{2}$ up to $9.3 \mathrm{t} / \mathrm{hm}^{2}$ at planting spacing of $24 \mathrm{~cm} \times 30 \mathrm{~cm}$, using $75 \mathrm{~g}$ of seeds per tray scattered pattern, instead of performing cultivation and crop establishment manually. The results of this research confirm the performance of SRI practices in raising grain yield, which is fact stating this was achieved with reduced water and lowering resources (which offers greater benefits for the farmers and the country at large scale). 
The experiment can be employed to evaluate more rice cultivars with a view of comparing their performance to enhance granaries areas of rice production in different parts of Malaysia peninsula. Also the data collected from different parts of Malaysia will help assist commercial rice producers throughout the country on the management requirements of SRI i.e. nutrients and water application and control, land space, right age of seedling transplanting, morphological characteristics of young seedling and lastly the suitability of the modified planting finger (kukukambing) in meeting the requirements of SRI. Future research can be conducted to address the following questions of (i) the best age for seedlings to be transplanted using other modified transplanter and planting finger, (ii) the combination of other soil and other variety of rice plant characteristics, (iii) the expected response in terms of attainable yield and (iv) increase the yield of rice productivity in other major Asian rice producer countries in general and other Malaysian States in particular.

\section{Acknowledgement}

We acknowledge the financial support by the German Research Foundation and the Open Access Publication Fund of the Technische Universitaet Berlin.

\section{[References]}

[1] Papademetriou M K. Rice production in the Asia-Pacific region: issues and perspectives. Bridg. rice yield gap Asia-Pacific Reg. MK Papademetriou, FJ Dent, EM Herath), 2000; pp.4-25.

[2] de Laulanié $H$. Technical Presentation of the System of Rice Intensification, based on Katayama's Tillering model. Tropicultura, 1993; $22 \mathrm{p}$.

[3] Gujja B, Thiyagarajan T M. New Hope for Indian Food Security?: The System of Rice Intensification. International Institute for Environment and Development London, 2009.

[4] Shamshiri R R, Ibrahim B, Ahmad D, Man H C, Wayayok A. An overview of the system of rice intensification for paddy fields of Malaysia. Indian J. Sci. Technol., 2018; 11(18).

[5] Amir U, Willem K, Norman S. Review of SRI modifications on rice crop and water management and research issues for making futher improvements in agricultural and water productivity. Paddy water Env., 2011; 9: 163-180.

[6] Uphoff N, Kassam A. Case study: System of rice intensification. Final report Agricultural Technologies for Developing Countries STOA Project "Agricultural Technologies for developing countries", FAO, Rome, 2009; pp.1-65.

[7] Sharif A. Technical adaptations for mechanized SRI production to achieve water saving and increased profitability in Punjab, Pakistan. Paddy Water Environ., 2011; 9(1): 111-119.

[8] Ling J, Teng Z S, Lin H J. Improved method for prediction of milled rice moisture content based on Weibull distribution. Int J Agric \& Biol Eng, 2018; 11(3): 159-165.

[9] Yu J X, Ren Y, Xu T, Li W, Xiong M T, Zhang T L, et al. Physicochemical water quality parameters in typical rice-crayfish integrated systems (RCIS) in China. Int J Agric \& Biol Eng, 2018; 11(3) $54-60$.

[10] Yang L, Zhao F, Chang Q, Li T, Li F. Effects of vermicomposts on tomato yield and quality and soil fertility in greenhouse under different soil water regimes. Agric. Water Manag., 2015; 160: 98-105.

[11] Rowshon M K, Iqbal M, Mojid M A, Amin M S M, Lai S H. Optimization of equitable irrigation water delivery for a large-scale rice irrigation scheme. Int J Agric \& Biol Eng, 2018; 11(5): 160-166.

[12] Choudhary R L, Dinesh K, Shivay Y S, Geeta S, Nain S. Performance of rice (Oryza sativa) hybrids grown by the system of rice intensification with plant growth-promoting rhizobacteria. Indian J. Agric. Sci., 2010; 80(10): 917-920.

[13] Mishra J S, Singh V P, Bhanu C, Subrahmanyam D. Crop establishment, tillage and weed management techniques on weed dynamics and productivity of rice (Oryza sativa)-chickpea (Cicer arietinum) cropping system. Indian J. Agric. Sci., 2012; 82(1).
[14] Dixit A, Khurana R, Singh J, Singh G. Comparative performance of different paddy transplanters developed in India-A Review. Practice, 2007; 28(4).

[15] Zhang M H, Wang Z M, Luo X W, Zang Y, Yang W W, Xing H, et al. Review of precision rice hill-drop drilling technology and machine for paddy. Int J Agric \& Biol Eng, 2018; 11(3): 1-11.

[16] Yin $X$, Du J, Noguchi N, Yang T X, Jin C Q. Development of autonomous navigation system for rice transplanter. Int J Agric \& Biol Eng, 2018; 11(6): 89-94.

[17] Wang B L, Luo X W, Wang Z M, Zheng L, Zhang M H, Dai Y Z, et al. Design and field evaluation of hill-drop pneumatic central cylinder direct-seeding machine for hybrid rice. Int J Agric \& Biol Eng, 2018; 11(6): 33-40.

[18] Li J Y, Lan Y B, Zhou Z Y, Zeng S, Huang C, Yao W X, et al. Design and test of operation parameters for rice air broadcasting by unmanned aerial vehicle. Int J Agric \& Biol Eng, 2016; 9(5): 24-32.

[19] Zhang G Z, Zang Y, Luo X W, Wang Z M, Zhang Q, Zhang S S. Design and indoor simulated experiment of pneumatic rice seed drilling metering device. Int J Agric \& Biol Eng, 2015; 8(4): 10-18.

[20] Chen Q, He A, Wang W, Peng S, Huang J, Cui K, Nie L. Comparisons of regeneration rate and yields performance between inbred and hybrid rice cultivars in a direct seeding rice-ratoon rice system in central China. F. Crop. Res., 2018; 223: 164-170.

[21] Hasanuzzaman M, Rahman M L, Roy T S, Ahmed J U, Zobaer A S M. Plant characters, yield components and yield of late transplanted Aman rice as affected by plant spacing and number of seedling per hill. Adv. Biol. Res. (Rennes)., 2009; 3(5-6): 201-207.

[22] Hossain M S, Mamun A A, Basak R, Newaj M N, Anam M K. Effect of cultivar and spacing on weed infestation and performance of transplanted aman rice in Bangladesh. Pakistan J. Agron, 2003; 2(3): 169-178.

[23] Chauhan B S, Johnson D E. Implications of narrow crop row spacing and delayed Echinochloa colona and Echinochloa crus-galli emergence for weed growth and crop yield loss in aerobic rice. F. Crop. Res., 2010; 117(2-3): 177-182

[24] Dass A, Shekhawat K, Choudhary A K, Sepat S, Rathore S S, Mahajan G, Chauhan B S. Weed management in rice using crop competition-a review. Crop Prot., 2017; 95: 45-52.

[25] Thakur A K, Mandal K G, Mohanty R K, Ambast S K. Rice root growth photosynthesis, yield and water productivity improvements through modifying cultivation practices and water management. Agric. Water Manag., 2018; 206: 67-77.

[26] Tomar R, Singh N B, Singh V, Kumar D. Effect of planting methods and integrated nutrient management on growth parameters, yield and economics of rice. J. Pharmacogn. Phytochem., 2018; 7(2): 520-527.

[27] Yamane K, Araki C, Watanabe Y, Iijima M. Close mixed planting with pearl millet improves drought tolerance in rice by the increased access to deep water. Plant Soil, 2018; 423(1-2): 397-410.

[28] Kandil A A, El-Kalla S E, Badawi A T, El-Shayb O M. Effect of hill spacing, nitrogen levels and harvest date on rice productivity and grain quality. Crop Environ., 2010; 1(1): 22-26.

[29] Chauhan B S, Johnson D E. Row spacing and weed control timing affect yield of aerobic rice. F. Crop. Res., 2011; 121(2): 226-231.

[30] Chauhan B S, Singh V P, Kumar A, Johnson D E. Relations of rice seeding rates to crop and weed growth in aerobic rice. F. Crop. Res., 2011; 121(1): 105-115.

[31] Zhao H X, Wang X X, Guio Z H, Huang X Q, Liu H L. Effects of row-spacing on canopy structure and yield in different plant type rice cultivars," J. Northeast Agric. Univ. (English Ed.), 2012; 19(4): 11-19.

[32] Bhowmik S K, Sarkar M A R, Zaman F. Effect of spacing and number of seedlings per hill on the performance of aus rice cv. NERICA 1 under dry direct seeded rice (DDSR) system of cultivation. J. Bangladesh Agril. Univ, 2012; 10(2): 191-195.

[33] Singh K, Singh S R, Singh J K, Rathore R S, Singh S P, Roy R. Effect of age of seedling and spacing on yield, economics, soil health and digestibility of rice (Oryza sativa) genotypes under system of rice intensification. Indian J. Agric. Sci., 2013; 83(5): 479-483.

[34] Chauhan B S, Opeña J L. Effect of plant spacing on growth and grain yield of soybean. American Journal of Plant Sciences, 2013; 2013 2011-2014. DOI: 10.4236/ajps.2013.410251.

[35] Moro B, Nuhu I, Martin E. Effect of spacing on grain yield and yield attributes of three rice (Oryza sativa L.) Varieties Grown in Rain-fed Lowland Ecosystem in Ghana. Int. J. Plant Soil Sci., 2016; 9(3): 1-10.

[36] Krishna A, Biradarpatil N K. Influence of seedling age and spacing on 
seed yield and quality of short duration rice under system of rice intensification cultivation. Karnataka J. Agric. Sci., 2009; 22(1): 53-55.

[37] Salem A K M. Effect of nitrogen levels, plant spacing and time of farmyard manure application on the productivity of rice. J. Appl. Sci. Res., 2006; 2(11): 980-987.

[38] Bozorgi H R, Faraji A, Danesh R K, Keshavarz A, Azarpour E, Tarighi F. Effect of plant density on yield and yield components of rice. World Appl Sci. J., 2011; 12(11): 2053-2057.

[39] Li L H, Wan C, Zhang X Y, Li G Y. Improvement and optimization of preparation process of seedling-growing bowl tray made of paddy straw. Int J Agric \& Biol Eng, 2014; 7(4): 13-22.

[40] Xu C L, Zhang C L, Li L H, Li M J. Optimization of working parameters for puddling and flatting machine in paddy field. Int $\mathrm{J}$ Agric \& Biol Eng, 2016; 9(3): 88-96.

[41] Lakitan B, Hadi B, Herlinda S, Siaga E, Widuri L I, Kartika K, et al. Recognizing farmers' practices and constraints for intensifying rice production at Riparian Wetlands in Indonesia. NJAS-Wageningen J. Life Sci., 2018; 85: 10-20

[42] Mobasser H R, Delarestaghi M M, Khorgami A, Tari B D, Pourkalhor H. Effect of planting density on agronomical characteristics of rice (Oryza sativa L.) varieties in North of Iran. Pak. J. Biol. Sci, 2007; 10(18): 3205-3209.

[43] Donkor E, Owusu V, Owusu-Sekyere E, Ogundeji A. The Adoption of Farm Innovations among Rice Producers in Northern Ghana: Implications for Sustainable Rice Supply. Agriculture, 2018; 8(8): 121.

[44] Towa J J, Guo X P. Effects of irrigation and weed-control methods on growth of weed and rice. Int J Agric \& Biol Eng, 2014; 7(5): 22-33.

[45] Omin E, Shayeb M A. Agronomic study on rice crop. MSc thesis, Mansoura Univ. Egypt, 2003; 164p.

[46] Islam H M D, Hossain S M A. Effect of fertilization and planting density on the yield of two varieties of fine rice. Pakistan J. Biol. Sci., 2002; 5(5) 511-513.

[47] Zahran H A A. Response of some rice cultivars to different spaces among hills and rows under saline soil conditions. Master Sci. Thesis, Facator Agric. Mansoura Univ. Egypt, 2000.

[48] Bassal S A A, Zahran F A. Effect of farmyard manure, bio and mineral nitrogen fertilizer and hill spaces on rice crop productivity. J. Agric. Sci. Mansoura Univ, 2002; 27(4): 1975-1988.

[49] Durairaj G. Design, development and field evaluation of manually operated rice transplanter for system of rice intensification. Int. J. Agric. Environ. Biotechnol., 2015; 8(3): 735.

[50] Neog P, Dihingia P C, Sarma P K, Sankar G R M, Sarmah D, Sarmah M K, et al. Different levels of energy use and corresponding output energy in paddy cultivation in North Bank Plain Zone of Assam, India," Indian J. Dryl. Agric. Res. Dev, 2015; 30(2): 84-92.

[51] Shukla U N, Srivastava V K, Singh S, Sen A, Kumar V. Growth, yield and economic potential of rice (oryza sativa) as influenced by different age of seedlings, cultivars and weed management under system of rice intensification. Indian J. Agric. Sci., 2014; 84(5): 80-88.

[52] Jabatan Pertanian Semenanjung Malaysia. Perangkaan Padi Malaysia., 2015; pp.1-106.

[53] Fornace K M, Abidin T R, Alexander N, Brock P, Grigg M J, Murphy A, et al. Association between landscape factors and spatial patterns of Plasmodium knowlesi infections in Sabah, Malaysia. Emerg. Infect. Dis., 2016; 22(2): 201.

[54] Thakur A K, Uphoff N T, Stoop W A. Scientific Underpinnings of the System of Rice Intensification (SRI): What is known so far? in Advances in Agronomy, Elsevier, 2016; 135: 147-179.

[55] Gardner W H. Water content. Methods of soil analysis: Part 1. Physical and mineralogical properties, including statistics of measurement and sampling, ed. CA. Black. Am. Soc. Agron. Madison, Wisconsin, 1983; 82: 127.

[56] ASTMD5435 - 13: Standard Test Method for Diagnostic Soil Test for Plant Growth and Food Chain Protection, 1998.

[57] Blake G R, Hartge K H. Bulk Density 1. Methods soil analysis, Part 1: physical and mineralogical methods (2nd edition), A. Klute, Ed., 1986, American Society of Agronomy, Agronomy Monographs 9(1), Madison, Wisconsin, 1986; pp.363-375.

[58] Ryan J, Estefan G, Rashid A. Soil and plant analysis laboratory manual. ICARDA, 2007.
[59] Garg I K, Mittal V K, Sharma V K. Effect of ground contact pressure and soil settlement period on paddy transplanter sinkage. J. Agric. Eng., 2000 37(1): 65-70.

[60] Shamshiri R. Measuring optimality degrees of microclimate parameters in protected cultivation of tomato under tropical climate condition. Measurement, 2017; 106: 236-244.

[61] Behera B K, Varshney B P, Goel A K. Effect of puddling on puddled soil characteristics and performance of self-propelled transplanter in rice crop. Agric. Eng. Int. CIGR J., 2009.

[62] Goel A K, Behera D, Swain S. Effect of sedimentation period on performance of rice transplanter. Agric. Eng. Int. CIGR J., 2008.

[63] Mufti A I, Khan A S. Performance evaluation of Yanmar paddy transplanter in Pakistan. Agric. Mech. ASIA AFRICA Lat. Am., 1995; 26 31.

[64] Prasad S M, Mishra S S, Singh S J. Effect of establishment methods, fertility levels and weed-management practices on rice (Oryza sativa). Indian J. Agron., 2001; 46(2): 216-221.

[65] Aslam M, Hussain S, Ramzan M, Akhter M. Effect of different stand establishment techniques on rice yields and its attributes. J. Anim. Pl. Sci, 2008; 18(2-3): 80-82

[66] Thomas V, Ramzi A M. SRI contributions to rice production dealing with water management constraints in northeastern Afghanistan. Paddy Water Environ., 2011; 9(1): 101-109.

[67] Ginigaddara G A S, Ranamukhaarachchi S L. Study of age of seedlings at transplanting on growth dynamics and yield of rice under alternating flooding and suspension of irrigation of water management. Recent Res. Sci. Technol., 2011;3(3).

[68] Pasuquin E, Lafarge T, Tubana B. Transplanting young seedlings in irrigated rice fields: early and high tiller production enhanced grain yield. F. Crop. Res., 2008; 105(1-2): 141-155.

[69] Van Quyen N, Tan P S, Van Hach C, Van Du P, Zhong X. Healthy rice canopy for optimal production and profitability. Omonrice, 2004; 12: 69-74.

[70] Tuong T P, Bouman B A M, Mortimer M. More rice, less water-integrated approaches for increasing water productivity in irrigated rice based systems in Asia. Plant Prod. Sci., 2005; 8(3): 229-239.

[71] Thakur A K, Uphoff N, Antony E. An assessment of physiological effects of system of rice intensification (SRI) practices compared with recommended rice cultivation practices in India. Exp. Agric., 2010; 46(1) 77-98.

[72] Kamboj B R, Yadav D B, Yadav A, Goel N K, Gill G, Malik R K, et al. Mechanized transplanting of rice (Oryza sativa L.) in nonpuddled and no-till conditions in the rice-wheat cropping system in Haryana, India," Am. J. Plant Sci., 2013; 4(12): 2409.

[73] Krishna A. Influence of system of rice intensification (SRI) cultivation on seed yield and quality Karnataka J Agric Sci, 2008; 21(3): 369-372.

[74] Faruk M O, Rahman M A, Hasan M A. Effect of seedling age and number of seedling per hill on the yield and yield contributing characters of BRRI Dhan 33. Int. J. Sustain. Crop Prod., 2009; 4(1): 58-61.

[75] Ceesay M, Reid W S, Fernandes E C M, Uphoff N T. The effects of repeated soil wetting and drying on lowland rice yield with System of Rice Intensification (SRI) methods. Int. J. Agric. Sustain., 2006; 4(1): 5-14.

[76] Kassam A, Stoop W, Uphoff N. Review of SRI modifications in rice crop and water management and research issues for making further improvements in agricultural and water productivity. Paddy Water Environ., 2011; 9(1): 163-180.

[77] Zheng J G, Lu X J, Jiang X L, Tang Y L. The system of rice intensification (SRI) for super-high yields in rice in Sichuan Basin. in Poster for 4th International Crop Science Congress, September, Brisbane, Australia, 2004

[78] Farooq M, Basra S M A, Karim H A, Afzal I. Optimization of seed hardening techniques for rice seed invigoration. Emirates J. Food Agric., 2004; 16: 48-57.

[79] Xie X J, Li B B, Shen S H. Impact of high temperature stress on photosynthetic characteristic and yield of rice (Oryza sativa) at heading. Indian J. Agric. Sci., 2012; 82(6).

[80] Zain N A M, Ismail M R, Mahmood M, Puteh A, Ibrahim M H. Alleviation of water stress effects on MR220 rice by application of periodical water stress and potassium fertilization. Molecules, 2014; 19(2): 1795-1819. 